\title{
Preparation and Characterization of Thiosemicarbazones Corrosion Inhibition Effect and the Antimicrobial and Anticancer Effect on their Metal Complexes
}

\author{
Tahani I. Kashar \\ Department of Chemistry, Faculty of Arts and Science, \\ Qassim University, Saudi Arabia \\ Department of Chemistry, Faculty of Science, \\ Menoufia University, Shebin El-Kom, Egypt \\ Marwa Abdel-Motaal \\ Department of Chemistry, Faculty of Arts and Science, \\ Qassim University, Saudi Arabia
}

Department of Chemistry, Faculty of Science, Mansoura University, Egypt

\section{Khadija Emran}

Department of Chemistry, College of Science,

Taibah University, Almadina, Saudi Arabia

Noha A. Sukar

Department of Chemistry, Faculty of Arts and Science,

Qassim University, Saudi Arabia

Department of Chemistry, Faculty of Science, Al-Azhar University, Egypt

doi: 10.19044/esj.2016.v13n3p249 URL:http://dx.doi.org/10.19044/esj.2016.v13n3p249

\begin{abstract}
Benzofurane and naphthofuranethiosemicarbazone ligands 2a $\left(\mathbf{L}^{\mathbf{1}}\right)$ and $\mathbf{2 b}\left(\mathbf{L}^{2}\right)$ and their $\mathrm{Cu}(\mathrm{II}), \mathrm{Co}(\mathrm{II}), \mathrm{Ni}(\mathrm{II})$, and $\mathrm{Pd}(\mathrm{II})$ complexes have been synthesized and characterized by elemental analyses, molar conductance, magnetic susceptibility measurements, IR, NMR, and electronic spectral studies. IR spectra show that the ligands is coordinated to the metal ions in a didentate manner with $\mathrm{N}, \mathrm{S}$ doner sites. In the presence of tow thiosemicarbazones ligands $\mathbf{2} \mathbf{a}\left(\mathbf{L}^{\mathbf{1}}\right)$ and $\mathbf{2} \mathbf{b}\left(\mathbf{L}^{2}\right)$, the corrosion resistance of cast iron in 10. $\mathrm{M} \mathrm{H}_{2} \mathrm{SO}_{4}$ increases in the order, $\mathbf{2} \mathbf{b}\left(\mathbf{L}^{2}\right)>\mathbf{2 a}\left(\mathbf{L}^{\mathbf{1}}\right)$. The effect of studied ligands inhibits the corrosion of cast iron extent depending on the structure and high donation of $\pi$-electron present inhibitor. Co(II) and Pd (II) complexes possess higher antimicrobial activity than free ligands and other complexes. The $\left[\mathrm{L}^{1} \mathrm{Pd} \mathrm{Cl} \mathrm{Cl}_{2}\right] \mathrm{H}_{2} \mathrm{O}$ complexe shows higher IC50 value of 4.6 $\mu \mathrm{g} / \mathrm{ml}$ toward human breast cancer cell lines (MCF-7). For other complexes,
\end{abstract}


they are in the range of $2.7-4.3 \mu \mathrm{g} / \mathrm{ml}$ toward the former cells which is related to their metal complexing ability in enzymes.

Keywords: Synthesis, Corrosion inhibition, metal complexes, antibacterial, antifungal, anticancer effect

\section{Introduction}

Thiosemicarbazones have many extensive applications such as antibacterial (Parekh \& Desai, 2006; Chandra \& Gupta, 2005; Demertzi et al., 1999; Ferrari et al., 1998; Ferrari et al., 2000), antifungal (Bhat et al., 1972), antiviral (Lobana et al., 2006), antiamoebic (Sharrma et al., 2005), antimalarial (Klayman et al.,1979; Klayman et al., 1984), and antitumor activity (Liberta \& West, 1993). Thus, their derivatives have been reported to be a potential inhibitor for metals (Arab \& Emran, 2008; Badr, 2009; AbdEl-Nabey et al., 2012; Karakus \& Sayin, 2015; Obot et al., 2009). These compounds were formed by the condensation of thiosemicarbazide and aldehyde or ketone, and it is not surprising that numerous thiosemicarbazone complexes have been prepared and characterized (Kashar \& Emran, 2016). However, various studies of thiosemicarbazone derivatives include; investigations of corrosion inhibitors for metal alloy (Arab \& Emran, 2008), fluorometry, atomic absorption spectrophotometry, and chemical sensors (Yadav et al., 2013), supramolecular chemistry (Anirudhan et al., 2013), optoelectronics (Garg \& Jain, 1988), and pharmacological activity (Khanye et al., 2011). Benzofuran, naphthofuran, and their derivatives have received considerable attention due to their occurrence in nature (Lumb \& Trauner, 2005; Akyul \& Anil, 2004). In addition, some naturally occurring substances of these compounds exhibit a variety of interesting pharmacological activity (Paul et al., 2008; Carlsson et al., 2002). Furthermore, a lot of members of this family are widely used in pharmaceutical applications (Hanumanagoud \& Basavaraja, 2013; Milan \& Acharya, 2015). This is as a result of the importance of these compounds which is utilized as synthetic block in organic synthesis (Xiang, 2010; Cumhur, 2009). Also, they are used as ligand (Halli et al., 2012; Sumathi \& Halli, 2014) for the synthesis of biologically active complexes.

Cast iron is widely used for water carrying purposes besides mild steel and other metals. However, the corrosion of cast iron is a serious problem for pipe line industry. In order to minimize corrosion problem, there are various ways of protecting metals from corrosion (oxidation). These methods include protective coatings, modification of the metal, modification of surface conditions, and inhibition of surface reaction. Among these methods, the use of chemical inhibitors remained the most cost effective and practical method. Therefore, the development of new organic compounds containing nitrogen, 
sulphur, and oxygen atoms are of growing interest in the field of corrosion and industrial chemistry. This is because corrosion poses serious problem to the service lifetime of alloys used in industry (Mansfeld et al., 1985).

In this study, ligands 1-(1- (5-hydroxy-2-methylbenzofuran-3-yl) ethylidene) thiosemicarbazone $2 \mathrm{a}\left(\mathrm{L}^{1}\right)$ and 1-(1-(5-hydroxy-2methylnaphtho[1,2-b]furan-3-yl)ethylidene)thiosemicarbazone $2 \mathrm{~b}\left(\mathrm{~L}^{2}\right)$ and their metallic complexes were prepared and characterized by molar conductance, magnetic susceptibility measurements, and ultra-violet and infrared spectroscopy. Corrosion inhibition efficiency and parameters which was influenced by the new thiosemicarbazones (ligands) concentration were described in $1.0 \mathrm{M} \mathrm{H}_{2} \mathrm{SO}_{4}$ by electrochemical methods. Also, the antibacterial activities of the ligands and their complexes were evaluated by measuring the zone of inhibition using disc diffusion method against Gram positive bacteria Staphylococcus aureus, Staphylococcus epidermidis and Gram negative bacteria Escherichia coli, and Pseudomonas aureginosa. Therefore, the results of the cytotoxic activity in vitro were expressed as IC50.

\section{Experimental Procedure}

\section{Synthesis of the Thiosemicarbazone Ligands}

A mixture of 1-(1- (5-hydroxy-2-methylbenzofuran-3-yl) ethylidene(1a) or 1- (1-(5-hydroxy-2-methylnaphtho[1,2-b]furan-3-yl) ethylidene $(1 \mathrm{~b})(0.01 \mathrm{~mol})$ and thiosemicarbazid $(0.01 \mathrm{~mol})$ was added in a $20 \mathrm{ml}$ ethanol. The mixture was refluxed for $8 \mathrm{~h}$, concentrated, and cooled. The precipitate which was formed was filtered off, dried, and was crystallized from a given solvent to give thiosemicarbazones $2 a\left(\mathrm{~L}^{1}\right)$ or $2 \mathrm{~b}\left(\mathrm{~L}^{2}\right)$ as white needles. 
<smiles>CC(=O)c1c(C)oc2ccc(O)cc12</smiles>

$1 a$

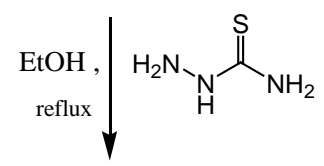<smiles>C/C(=N/NC(N)=S)c1c(C)oc2ccc(O)cc12</smiles>

2a<smiles>CC(=O)c1c(C)oc2c1cc(O)c1ccccc12</smiles>

$1 \mathbf{b}$<smiles>CCOCCN(C)/C(C)=N/NC(N)=S</smiles>

Scheme 1. Synthesis of the benzofurane and naphthofuranethiosemicarbazone ligands 1-(1- (5-hydroxy-2-methylbenzofuran-3-yl) ethylidene) thiosemicarbazone(2a) L1 Recrystallization from dilute ethanol, yield $89 \%$,. IR (KBr):v3479, 3354, 3277, 3182 (-OH, $\left.\mathrm{NH}_{2}, \mathrm{NH}\right), 1627 \mathrm{~cm}^{-1}(\mathrm{C}=\mathrm{N})$ and $1570 \mathrm{~cm}^{-1}(\mathrm{C}=\mathrm{S}){ }^{1} \mathrm{H}-\mathrm{NMR}$ (DMSO): $\delta 1.8\left(\mathrm{~s}, 3 \mathrm{H}, \mathrm{CH}_{3}-\mathrm{O}-\right)$, $2.2\left(\mathrm{~s}, 3 \mathrm{H}, \mathrm{CNCH}_{3}\right), 3.7$ (s, $\left.1 \mathrm{H}, \mathrm{OH}\right), 6.5-7.6$ (m, 3H, $\left.\mathrm{Ar}-\mathrm{H}\right), 7.8\left(\mathrm{~s}, 2 \mathrm{H}, \mathrm{NH}_{2}\right.$ ). and $8.5 \mathrm{ppm}$ (s, 1H, NH).

1-(1-(5-hydroxy-2-methylnaphtho[1,2-b]furan3yl)ethylidene)thiosemicarbazone (2b) $\mathbf{L}^{2}$ Recrystallization from ethanol yield $80 \%$. IR (KBr):v3435, 3362, 3235, $3112\left(-\mathrm{OH}, \mathrm{NH}_{2}\right.$, $\mathrm{NH}), 1641 \mathrm{~cm}^{-1}(\mathrm{C}=\mathrm{N}) 1588 \mathrm{~cm}^{-1}(\mathrm{C}=\mathrm{S}) .{ }^{1} \mathrm{H}-\mathrm{NMR}$ (DMSO): $\delta 2.3$ (s, 3H, CH$\left.-\mathrm{O}-\right), 2.5$ (s, 3H, $\left.\mathrm{CNCH}_{3}\right), 2.8\left(\mathrm{~s}, 2 \mathrm{H}, \mathrm{NH}_{2}\right), 7-8.2(\mathrm{~m}, 3 \mathrm{H}, \mathrm{Ar}-\mathrm{H}), 10.0(\mathrm{~s}, 1 \mathrm{H}, \mathrm{OH})$, and $10.3 \mathrm{ppm}(\mathrm{s}, 1 \mathrm{H}$, $\mathrm{NH})$. MS $[\mathrm{m} / \mathrm{z}](\%): 313\left[\mathrm{M}^{+}\right](9.0), 296$ (16.8), 268 (1.58), 254 (100), 238 (29.24), 223(21.67).

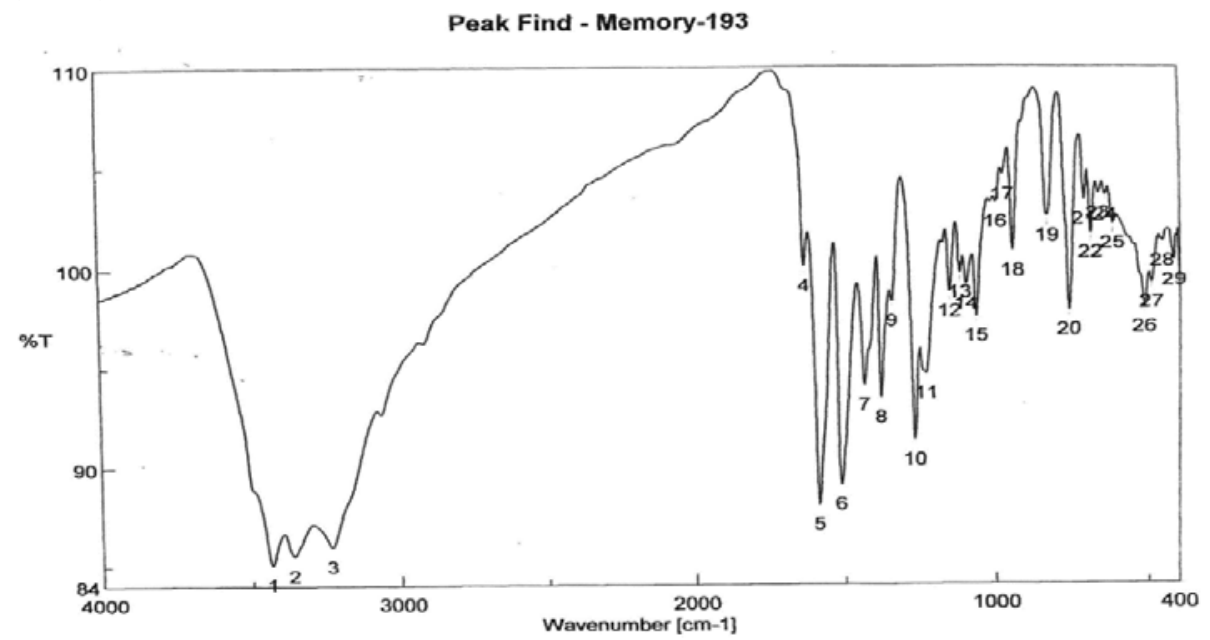

Figure 1. IR spectrum of the ligand $\left(\mathrm{L}^{2}\right)$ 


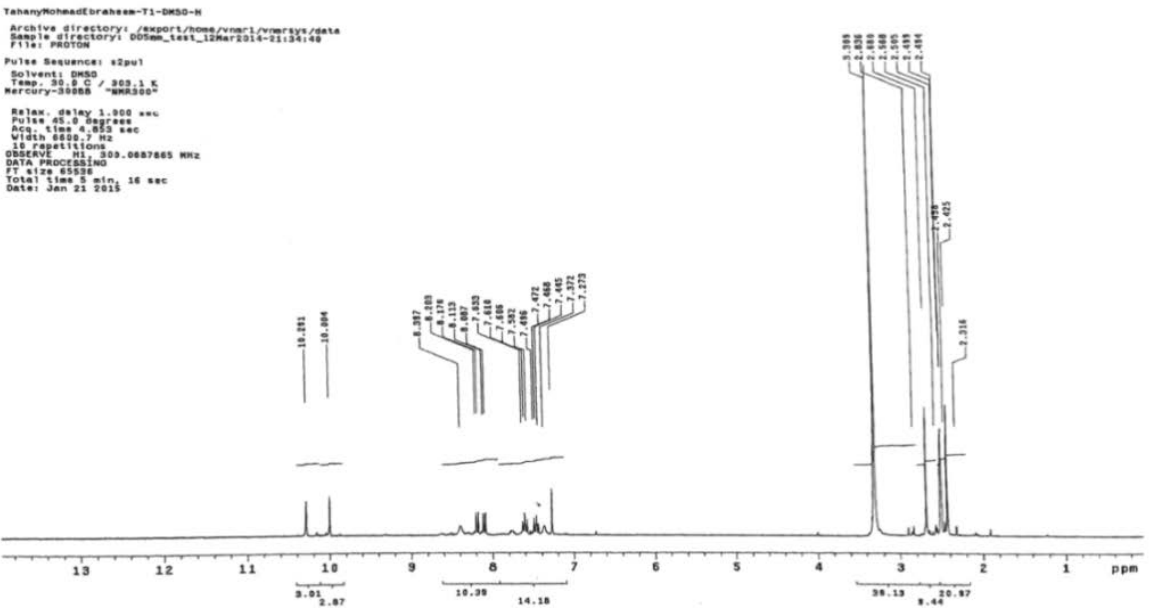

Figure 2. $\mathrm{H}^{1} \mathrm{NMR}$ spectrum of the ligand $\left(\mathrm{L}^{2}\right)$ in DMSO

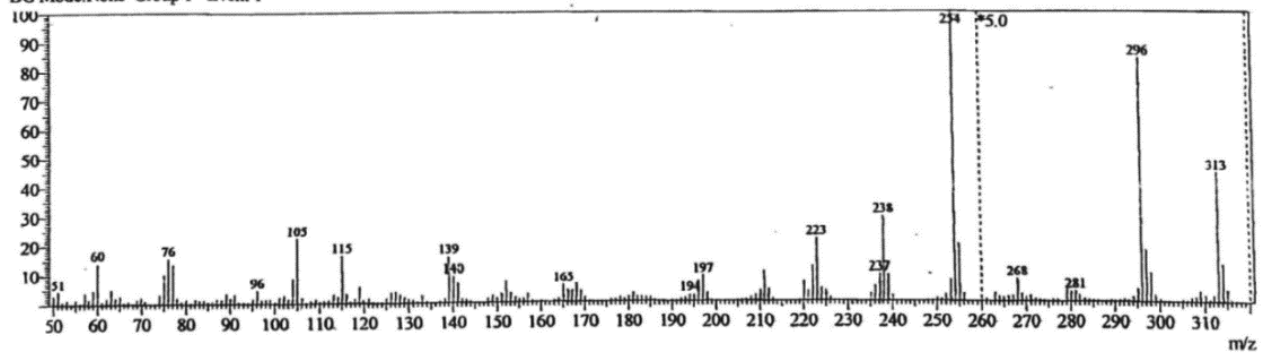

Figure 3. Mass spectrum of the ligand $\left(\mathrm{L}^{2}\right)$

\section{Measurements}

All chemicals and solvents used were from BDH or Aldrich. Melting points are in degree centigrade and are uncorrected. Infrared spectra were recorded on a Mattson - 5000 FTIR spectrometer using potassium bromide wafer technique. ${ }^{1} \mathrm{H}-\mathrm{NMR}$ spectra were determined on a Varian Gemini $200 \mathrm{MHz}$. and jeol-Ex-250 $\mathrm{MHz} \mathrm{NMR}$ spectrometer in $\mathrm{CDCl}_{3}$ or $\mathrm{DMSO}$ solvent. This was done using TMS as an internal standard (chemical shift $\delta=0 \mathrm{ppm})$. Mass spectra were determined on a GC-MS. Qp-1000 Ex (Shimadzu, Japan). The purity of the synthesized compounds was tested by thin layer chromatography (TLC), Merck plates. Elemental analyses (C, H, $\mathrm{N}, \mathrm{Cl}$, and $\mathrm{S}$ ) were carried out at the micro analytical Unit of the University of Cairo. Metal ions were determined using atomic absorption with a Perkin Elmer (model 2380) spectrophotometer. Electronic absorption spectra in the 200-900 nm regions were recorded on a Perkin-Elmer 550 
spectrophotometer. Also, thermal analyses (DTA and TGA) were carried out on a Shimadzu DT-30 and TG-50 thermal analyzers in the $27-800^{\circ} \mathrm{C}$ range at a heating rate of $10^{\circ} \mathrm{Cmin}^{-1}$. The magnetic susceptibilities were measured at room temperature using the Gouy method with mercuric tetrathiocyanatocobaltate(II) as magnetic susceptibility standard. Therefore, diamagnetic corrections were made using Pascal's constants. A Bibby conductimeter $\mathrm{MCl}$ was used for conductance measurements.

\section{Corrosion Measurements}

All electrochemical measurements were done using a model Interface $1000^{\mathrm{TM}}$, Gamry, supported by Potentiostat/Galvanostat/ZRA analyzer. DC105 ${ }^{\mathrm{TM}}$ DC electrochemical techniques software system in Gamry allows the making of the electrochemical tests on same sample and same solution using sequencer system. The study was performed in sequence: (1) Electrochemical frequency modulation using frequencies of 2 and $5 \mathrm{~Hz}$ with a reasonable limit of $10 \mathrm{~Hz}$. (2) Linear polarization resistance (LPR) within $\pm 20 \mathrm{mV}$ which is more noble or more active than the open circuit potential $\left(E_{\text {ocp}}\right)$. This technique is used to measure absolute corrosion rates in mils per year (mpy). (3) Galvanic corrosion measurements within 100s to calculate the rate of corrosion in millimeters per year (mmpy). (4) Electrochemical impedance measurements (frequency range of $1 \mathrm{kHz}-0.1 \mathrm{~Hz}$ and sinusoidal voltage of $10 \mathrm{mV}$ ). The impedance diagrams were plotted in the Nyquist representation. (5) Potentiodynamic measurements at a scan rate of $1 \mathrm{mV} / \mathrm{s}$. All electrochemical experiments were performed using a standard threeelectrode electrochemical cell at $27^{\circ} \mathrm{C}$. Experiments utilized $\mathrm{Ag} / \mathrm{AgCl}$ as the reference electrode, and $\mathrm{Pt}$ wire as the counter electrode. The aggressive solution, $1.0 \mathrm{M} \mathrm{H}_{2} \mathrm{SO}_{4}$, was prepared by the dilution of analytical grade $\mathrm{H}_{2} \mathrm{SO}_{4}$ with double distilled water. Tests were performed on cast iron specimen with weight percentage compositions as shown in Table1.

Table 1. Chemical compositions of cast iron specimen with weight percentage (\%W)

\begin{tabular}{cccccc}
\hline$\% \mathrm{C}$ & $\% \mathrm{Si}$ & $\% \mathrm{Mn}$ & $\% \mathrm{P}$ & $\% \mathrm{~S}$ & Remain \\
\hline $3.45-3.65$ & $2.40-2.70$ & $0.60-0.70$ & $0.17-0.26$ & $0.04-0.06$ & Fe \\
\hline
\end{tabular}

\section{Antimicrobial Activity}

The antimicrobial activities of the ligands and their metal complexes chemically prepared were determined using a modified Kirby-Bauer disc diffusion method (Bauer, 1966). Briefly, $100 \mu \mathrm{l}$ of the test bacterial/fungi were grown in $10 \mathrm{ml}$ of fresh media until they reached a count of approximately $10^{8}$ cells $/ \mathrm{ml}$ for bacteria or $10^{5}$ cells $/ \mathrm{ml}$ for fungi (Pfaller, 1988). $100 \mu \mathrm{l}$ of microbial suspension was spread on to agar plates. Blank paper disks (Schleicher \& Schuell, Spain) with a diameter of $8.0 \mathrm{~mm}$ were 
impregnated into $10 \mu \mathrm{l}$ of tested concentration of the stock solution of metal complexes. When a filter paper disc impregnated with a tested chemical is placed on the agar, the chemical will diffuse from the disc into the agar.

Subsequently, standard discs of Ampicillin (Antibacterial agent), Amphotericin B (Antifungal agent), served as positive controls for antimicrobial activity. However, filter disks impregnated with $10 \mu \mathrm{l}$ of solvent dimethylsulfoxide (DMSO) were used as a negative control. Plates was inoculated with filamentous fungi such as Aspergillus flavus at $25^{\circ} \mathrm{C}$ for 48 hours; Gram (+) bacteria such as Staphylococcus aureua was incubated at 35-37 ${ }^{0} \mathrm{C}$ for 24-48 hours; yeast such as Candida albicans was incubated at $30^{\circ} \mathrm{C}$ for 24-48 hours; and then the diameters of the inhibition zones were measured in millimeters (Bauer et al., 1966).

\section{Cytotoxic Activity}

Cytotoxic activity of the ligands and their metal complexes was carried out at the National Cancer Institute, Cairo University, Egypt by SRB assay using the method (Suresh et al., 2006). Breast carcinoma cell were plated in 96-multiwell plate $\left(10^{4}\right.$ cells/well) for $24 \mathrm{~h}$ before treatment with the metal complexes to allow the attachment of cell to the wall of the plate. Different concentration of the ligands and metal complexes under test (0, 2.5, $5,10,20 \mu \mathrm{g} / \mathrm{mL}$ ) which were added to the cell monolayer triplicate wells were prepared for each individual dose. Monolayer cells were incubated with the compounds for $48 \mathrm{~h}$ at $37{ }^{\circ} \mathrm{C}$ and in an atmosphere of $5 \% \mathrm{CO}_{2}$. After 48 $\mathrm{h}$, cells were fixed, washed, and stained with Sulfo-Rhoda-mine-B stain. Excess stain was washed with acetic acid. Also, attached stain was recovered with Tris EDTA buffer. Color intensity was measured in an ELISA reader. The relation between surviving fraction and drug concentration is plotted to get the survival curve of each tumor cell line after the specified compound.

\section{Results and Discussion}

In this paper, new compounds which contains benzofuran and naphthofuran-thiosemicarbazones were synthesized using the starting materials 1a,b (scheme 1) which was previously prepared (Musiol et al., 2010). Also, their structures were confirmed by the spectral data. The condensation of both 1a,b with thiosemicarbazide in ethanol afforded the corresponding thiosemicarbazones $\mathbf{2 a}, \mathbf{2} \mathbf{b}\left(\mathrm{L}^{1}, \mathrm{~L}^{2}\right)$ respectively (scheme $\mathbf{1}$ ). However, the structures of the synthesized thiosemicarbazones derivatives were in agreement with their spectral data. All the prepared complexes of $\mathrm{Cu}(\mathrm{II}), \mathrm{Co}(\mathrm{II}), \mathrm{Ni}(\mathrm{II})$, and $\mathrm{Pd}(\mathrm{II})$ are stable in air and are insoluble in most common organic solvents. The results of elemental analyses $(\mathrm{C}, \mathrm{H}, \mathrm{N}, \mathrm{S})$ with molecular formula and melting points are presented in Table 2. The molar conductance values indicated that all the complexes are nonconductance 
except $\left[\left(\mathrm{L}^{1}\right)_{2} \mathrm{Co}\right] \mathrm{Cl}_{2} \cdot \mathrm{H}_{2} \mathrm{O}$ and $\left[\left(\mathrm{L}^{2}\right)_{2} \mathrm{Pd}\right] \mathrm{Cl}_{2} \cdot 2 \mathrm{H}_{2} \mathrm{O}$ complexes. Therefore, the results obtained are in good agreement with those calculated for the suggested formulae.

Table 2. Analytical and physical data of thiosemicarbazones ligands and their complexes

\begin{tabular}{|c|c|c|c|c|c|c|c|c|c|c|c|c|}
\hline \multirow[b]{2}{*}{$\begin{array}{l}\mathrm{N} \\
\mathrm{o} .\end{array}$} & \multirow[b]{2}{*}{ Compound } & \multirow[b]{2}{*}{ Colour } & \multirow[b]{2}{*}{ M.wt } & \multirow[b]{2}{*}{ M.P̊C } & \multirow[b]{2}{*}{$\begin{array}{l}\text { Yiel } \\
\text { d\% }\end{array}$} & \multicolumn{6}{|c|}{ Anal.found (Calc.)\% } & \multirow{2}{*}{$\begin{array}{c}\Lambda \mathrm{oh} \\
\mathrm{m}- \\
{ }^{1} \mathrm{~cm}^{2} \\
\mathrm{~mol}^{-1}\end{array}$} \\
\hline & & & & & & $\% \mathrm{C}$ & $\% \mathrm{H}$ & $\% \mathrm{~N}$ & $\% \mathrm{M}$ & $\% \mathrm{~S}$ & $\% \mathrm{Cl}$ & \\
\hline 1 & $\mathrm{~L}^{1}\left(\mathrm{C}_{12} \mathrm{H}_{13} \mathrm{~N}_{3} \mathrm{O}_{2} \mathrm{~S}\right)$ & White & 263 & 79 & 89 & $\begin{array}{c}54.5 \\
(54.7)\end{array}$ & $\begin{array}{c}4.6 \\
(4.9)\end{array}$ & $\begin{array}{c}15.8 \\
16.0)(\end{array}$ & - & $\begin{array}{c}11.9 \\
(12.2)\end{array}$ & - & 15.5 \\
\hline 2 & {$\left[\mathrm{~L}^{1} \mathrm{Cu} \mathrm{Cl}{ }_{2}\right] \mathrm{H}_{2} \mathrm{O}$} & $\begin{array}{c}\text { Deep } \\
\text { brown }\end{array}$ & 397.5 & 200 & 80 & $\begin{array}{c}36.6 \\
(36.2) \\
\end{array}$ & $\begin{array}{c}35 \\
(3.3) \\
\end{array}$ & $\begin{array}{c}10.2 \\
(10.6) .\end{array}$ & $\begin{array}{c}16.5 \\
(16.0)\end{array}$ & $\begin{array}{c}8.4 \\
(8.7) \\
\end{array}$ & $\begin{array}{c}17.2 \\
(17.9)\end{array}$ & 23.5 \\
\hline 3 & {$\left[\left(\mathrm{~L}^{1}\right)_{2} \mathrm{Co}\right] \mathrm{Cl}_{2} \cdot \mathrm{H}_{2} \mathrm{O}$} & Grey & 673.9 & 104 & 75 & $\begin{array}{c}47.9 \\
(42.7)\end{array}$ & $\begin{array}{c}3.9 \\
(4.2)\end{array}$ & $\begin{array}{c}12.0 \\
(12.5)\end{array}$ & $\begin{array}{c}8.0 \\
(8.7)\end{array}$ & $\begin{array}{c}9.3 \\
(9.5)\end{array}$ & $\begin{array}{c}10.2 \\
(10.5)\end{array}$ & 120 \\
\hline 4 & {$\left[\mathrm{~L}^{1} \mathrm{Ni} \mathrm{Cl}_{2}\right] \mathrm{H}_{2} \mathrm{O}$} & Brown & 410.7 & 205 & 80 & $\begin{array}{c}35.4 \\
(35.1)\end{array}$ & $\begin{array}{c}3.8 \\
(3.7)\end{array}$ & $\begin{array}{c}10.4 \\
(10.2)\end{array}$ & $\begin{array}{c}14.5 \\
(14.3)\end{array}$ & $\begin{array}{c}7.9 \\
(7.8) \\
\end{array}$ & $\begin{array}{c}17.3 \\
(17.3 \\
\end{array}$ & 12.5 \\
\hline 5 & {$\left[\mathrm{~L}^{1} \mathrm{Pd} \mathrm{Cl}_{2}\right] \mathrm{H}_{2} \mathrm{O}$} & $\begin{array}{c}\text { Pale } \\
\text { Brown }\end{array}$ & 458.4 & $>300$ & 80 & $\begin{array}{c}31.0 \\
(31.4)\end{array}$ & $\begin{array}{c}3.5 \\
(3.2)\end{array}$ & $\begin{array}{c}9.5 \\
9.2)(\end{array}$ & $\begin{array}{c}22.6 \\
22.2)(\end{array}$ & $\begin{array}{c}7.5 \\
(7.0)\end{array}$ & $\begin{array}{c}15.0 \\
(15.5)\end{array}$ & 24.0 \\
\hline 6 & {$\left[\mathrm{~L}^{1} \mathrm{Cu} \mathrm{Ac}_{2}\right] \mathrm{H}_{2} \mathrm{O}$} & Brown & 462.5 & $>300$ & 90 & $\begin{array}{c}41.0 \\
(41.5)\end{array}$ & $\begin{array}{c}5.2 \\
5.4)(\end{array}$ & $\begin{array}{c}9.3 \\
9.1)(\end{array}$ & $\begin{array}{c}13.4 \\
(13.7)\end{array}$ & $\begin{array}{c}7.0 \\
(6.7)\end{array}$ & - & 23.0 \\
\hline 7 & $\mathrm{~L}^{2}\left(\mathrm{C}_{16} \mathrm{H}_{15} \mathrm{~N}_{3} \mathrm{O}_{2} \mathrm{~S}\right)$ & White & 313 & 105 & 80 & $\begin{array}{c}61.6 \\
(61.3)\end{array}$ & $\begin{array}{c}4.5 \\
(4.8)\end{array}$ & $\begin{array}{c}13.0 \\
(13.4)\end{array}$ & - & $\begin{array}{c}9.9 \\
(10.2)\end{array}$ & - & 18.5 \\
\hline 8 & {$\left[\mathrm{~L}^{2} \mathrm{Cu} \mathrm{Cl}{ }_{2}\right] \mathrm{H}_{2} \mathrm{O}$} & $\begin{array}{l}\text { Pale } \\
\text { Brown }\end{array}$ & 465.5 & 180 & 70 & $\begin{array}{c}41.3 \\
(41.2)\end{array}$ & $\begin{array}{c}3.5 \\
3.7)(\end{array}$ & $\begin{array}{c}9.4 \\
(9.0)\end{array}$ & $\begin{array}{c}13.5 \\
(13.6)\end{array}$ & $\begin{array}{c}6.6 \\
(6.8)\end{array}$ & $\begin{array}{c}15.0 \\
(15.3)\end{array}$ & 23.3 \\
\hline 9 & {$\left[\mathrm{~L}^{2} \mathrm{Co} \mathrm{Cl}_{2}\right] 2 \mathrm{H}_{2} \mathrm{O}$} & Brown & 478.9 & $300>$ & 90 & $\begin{array}{c}40.6 \\
40.1)(\end{array}$ & $\begin{array}{c}4.0 \\
4.0)(\end{array}$ & $\begin{array}{c}9.5 \\
8.8)(\end{array}$ & $\begin{array}{c}12.0 \\
12.3)(\end{array}$ & $\begin{array}{c}7.0 \\
(6.7)\end{array}$ & $\begin{array}{c}15.0 \\
(14.8\end{array}$ & 20.5 \\
\hline 10 & {$\left[\left[\mathrm{~L}^{2} \mathrm{Ni} \mathrm{Cl}_{2}\right] \mathrm{H}_{2} \mathrm{O}\right.$} & Brown & 460.7 & $300>$ & 80 & $\begin{array}{c}41.2 \\
(41.7)\end{array}$ & $\begin{array}{c}3.5 \\
3.7)(\end{array}$ & $\begin{array}{c}9.5 \\
9.1)(\end{array}$ & $\begin{array}{c}12.4 \\
(12.7)\end{array}$ & $\begin{array}{c}7.0 \\
(6.9)\end{array}$ & $\begin{array}{c}15.5 \\
(15.4)\end{array}$ & 17.0 \\
\hline 11 & {$\left[\left(\mathrm{~L}^{2}\right)_{2} \mathrm{Pd}\right] \mathrm{Cl}_{2} \cdot 2 \mathrm{H}_{2} \mathrm{O}$} & Brown & 839.4 & 227 & 75 & $\begin{array}{c}45.4 \\
(45.8)\end{array}$ & $\begin{array}{c}3.8 \\
(4.1)\end{array}$ & $\begin{array}{c}10.3 \\
(10.0)\end{array}$ & $\begin{array}{c}13.0 \\
(12.7)\end{array}$ & $\begin{array}{c}7.8 \\
(7.6)\end{array}$ & $\begin{array}{c}8.7 \\
(8.5)\end{array}$ & 130 \\
\hline
\end{tabular}

\section{IR and ${ }^{1} \mathrm{H}-\mathrm{NMR}$ Spectra}

In addition to the absence of an absorption band of the $\mathrm{C}=\mathrm{O}$ group, the IR spectra of $\mathbf{2} \mathbf{a}, \mathbf{b}\left(\mathrm{L}^{1}, \mathrm{~L}^{2}\right)$ showed that absorption bands appeared at 3479, 3354, 3277and $3182 \mathrm{~cm}^{-1}$ due to $-\mathrm{OH},-\mathrm{NH}_{2}$, and $\mathrm{NH}$ groups for $\mathbf{2 a}\left(\mathbf{L}^{1}\right)$ respectively and absorption bands at $v$ 3435, 3362, 3235, and $3112 \mathbf{c m}^{-1}$ for $\mathbf{2} \mathbf{b}\left(\mathbf{L}^{\mathbf{2}}\right)$ Fig.1. The ${ }^{1} \mathrm{H}-\mathrm{NMR}$ spectrum of $\mathbf{2 a}\left(\mathbf{L}^{\mathbf{1}}\right)$ beside the expected signals exhibited three singlet signals at $\delta 1.7,8.5$ and $8.7 \mathrm{ppm}$ characteristic for $\mathrm{OH}, \mathrm{NH}$ and $-\mathrm{NH}_{2}$ protons, respectively. On the other hand, the ${ }^{1} \mathrm{H}$-NMR spectrum of $\mathbf{2} \mathbf{b}\left(\mathbf{L}^{2}\right)$ revealed the presence of three singlet signals at 2.8, 10 , and $10.3 \mathrm{ppm}$ due to $\mathrm{OH}, \mathrm{NH}$, and $-\mathrm{NH}_{2}$ protons with the other expected signals as shown in Fig.2. The mass spectrum of $\mathbf{2} \mathbf{b}\left(\mathbf{L}^{2}\right)$ showed the molecular ion peak at $\mathrm{m} / \mathrm{z} 313\left(\mathrm{M}^{+}\right)$which is equivalent to the molecular formula $\left(\mathrm{C}_{16} \mathrm{H}_{15} \mathrm{~N}_{3} \mathrm{O}_{2} \mathrm{~S}\right)$ in addition to the base peak at $\mathrm{m} / \mathrm{z} 254$ due to the molecular ion after fragmentation of the $\mathrm{CSNH}_{2}$ as shown in Figure 3. IR spectra of compounds provide evidence regarding the bonding sites in the complexes. Thiosemicarbazones $\mathbf{2 a}, \mathbf{b}\left(\mathrm{L}^{1}, \mathrm{~L}^{2}\right)$ shows a broad band at 3479 , $3435 \mathrm{~cm}^{-1}$, indicating that there is free $\mathrm{OH}$ group involved. The interest in the IR spectra of the bidentate nitrogen donar ligands $2 a, 2 b\left(L^{1}, L^{2}\right)$ lies 
mainly in the peaks due to $(C=S)$ group and the $(C=N)$ groups at 1570 , $1588 \mathrm{~cm}^{-1}$ and $1627,1641 \mathrm{~cm}^{-1}$ respectively. The ligands exist in the thione form since they contain a thioamide function group. However, due to the absence of the $v(\mathrm{~S}-\mathrm{H})$ stretching in the region $2500-2600 \mathrm{~cm}^{-1}$, the IR spectra of ligands indicate that the ligand retain their thione form in the solid state. This is further inferred from the presence of a peak at $1570,1588 \mathrm{~cm}^{-1}$ due to the $v(C=S)$ stretching. The lowering of the frequency of $v(C=N)$ of $2 \mathbf{b}\left(\mathbf{L}^{2}\right)$ and the highering of the frequency of $\mathbf{2} \mathbf{a}\left(\mathbf{L}^{\mathbf{1}}\right)$ on complex formation supports the coordination through the azomethine nitrogen. The $v(C=S)$ in the complexes of $\mathbf{2 a}\left(\mathbf{L}^{\mathbf{1}}\right)$ or $\mathbf{2} \mathbf{b}\left(\mathbf{L}^{2}\right)$ shifted to lower frequency thereby indicating the involvement of the thione sulfur in complexes formation. The higher shift of $v \mathrm{~N}-\mathrm{N}$ which was observed on complexation confirmed the coordination of the azomethine nitrogen to the metal ions (Serda et al., 2012). Therefore, this shows that the nitrogen atom of the azomethine group reduces the electron density on the azomethine linkage. Thus, the prepared thiosemicarbazone ligands has N,S donor bidentate nature in these complexes as shown in Table 3. The new bands at $546-500 \mathrm{~cm}^{-1}$ and $390-375 \mathrm{~cm}^{-1}$ in the spectra of the complexes were attributed to the $v \mathrm{M}-\mathrm{N}$ and $v \mathrm{M}-\mathrm{S}$ vibrations, respectively (Guru et al., 2003).

Table 3. IR Spectra of thiosemicarbazones ligands and their complexes

\begin{tabular}{|c|c|c|c|c|c|c|c|c|}
\hline $\begin{array}{l}\mathrm{N} \\
\mathrm{o} .\end{array}$ & $\begin{array}{l}\text { Molecular } \\
\text { Formula }\end{array}$ & $\mathrm{OH} v$ & $\mathrm{NH}_{2} v$ & $\mathrm{NH} v$ & $\nu \mathrm{C}=\mathrm{N}$ & $\mathrm{C}=\mathrm{S} v$ & $\mathrm{M}-\mathrm{N} v$ & $\begin{array}{l}\text { M- } \\
\text { Sv }\end{array}$ \\
\hline 1 & $\begin{array}{c}\mathrm{L}^{1}\left(\mathrm{C}_{12} \mathrm{H}_{13} \mathrm{~N}_{3} \mathrm{O}_{2} \mathrm{~S}\right. \\
)\end{array}$ & $\begin{array}{c}3479(\mathrm{~s} \\
\text { ) }\end{array}$ & $\begin{array}{l}3354 \\
3277\end{array}$ & 3182 (s) & 1627(s) & $1570(s)$ & - & - \\
\hline 2 & {$\left[\mathrm{~L}^{1} \mathrm{Cu} \mathrm{Cl}{ }_{2}\right] \mathrm{H}_{2} \mathrm{O}$} & $\begin{array}{c}3400(b \\
r)\end{array}$ & & 3197(s) & $\begin{array}{c}16280(\mathrm{~s} \\
)\end{array}$ & 1564(s) & $529(\mathrm{~m})$ & 380 \\
\hline 3 & $\begin{array}{c}{\left[\left(\mathrm{L}^{1}\right)_{2} \mathrm{Co}\right]} \\
\mathrm{Cl}_{2} \cdot \mathrm{H}_{2} \mathrm{O}\end{array}$ & $\begin{array}{c}3412(b \\
r)\end{array}$ & $\begin{array}{l}3262( \\
\mathrm{m})\end{array}$ & 3186(s) & 1628(s) & $1546(s)$ & 533(m) & 390 \\
\hline 4 & {$\left[\mathrm{~L}^{1} \mathrm{Ni} \mathrm{Cl}_{2}\right] \mathrm{H}_{2} \mathrm{O}$} & $\begin{array}{c}3428( \\
w)\end{array}$ & & 3196(m) & 1630(s) & 1542(s) & 546(m) & 375 \\
\hline 5 & {$\left[\mathrm{~L}^{1} \mathrm{Pd} \mathrm{Cl}{ }_{2}\right] \mathrm{H}_{2} \mathrm{O}$} & $\begin{array}{c}3342(\mathrm{~s} \\
)\end{array}$ & $\begin{array}{c}3251(\mathrm{~s} \\
\text { ) }\end{array}$ & 3134(m) & 1632(s) & $\begin{array}{c}1564(\mathrm{~m} \\
)\end{array}$ & 537(m) & 390 \\
\hline 6 & {$\left[\mathrm{~L}^{1} \mathrm{Cu} \mathrm{Ac}_{2}\right] \mathrm{H}_{2} \mathrm{O}$} & $\begin{array}{c}3418(\mathrm{~s} \\
\text { ) }\end{array}$ & & & $1600(s)$ & 1521(s) & - & 385 \\
\hline 7 & $\begin{array}{c}\mathrm{L}^{2}\left(\mathrm{C}_{16} \mathrm{H}_{15} \mathrm{~N}_{3} \mathrm{O}_{2} \mathrm{~S}\right. \\
)\end{array}$ & $\begin{array}{c}3435(\mathrm{~s} \\
)\end{array}$ & $\begin{array}{l}3362, \\
3235\end{array}$ & 3235(s) & 1641(s) & 1588(s) & 541(m) & - \\
\hline 8 & {$\left[\mathrm{~L}^{2} \mathrm{Cu} \mathrm{Cl}_{2}\right] \mathrm{H}_{2} \mathrm{O}$} & $\begin{array}{c}3428(\mathrm{~s} \\
\text { ) }\end{array}$ & $\begin{array}{c}33406( \\
\text { s) }\end{array}$ & 3248(s) & $1600(\mathrm{~s})$ & $1525(\mathrm{~s})$ & $500(w)$ & 384 \\
\hline 9 & {$\left[\mathrm{~L}^{2} \mathrm{Co} \mathrm{Cl}_{2}\right] 2 \mathrm{H}_{2} \mathrm{O}$} & $\begin{array}{l}\text { 3403(b } \\
\text { r) }\end{array}$ & & & 1616(s) & $\begin{array}{c}\text { 1541(m } \\
\text { ) }\end{array}$ & $531(\mathrm{~m})$ & 395 \\
\hline 10 & {$\left[\left[\mathrm{~L}^{2} \mathrm{Ni} \mathrm{Cl}_{2}\right] \mathrm{H}_{2} \mathrm{O}\right.$} & $\begin{array}{c}3391(\mathrm{~s} \\
\text { ) }\end{array}$ & & & 1622(s) & $\begin{array}{c}1554(\mathrm{~m} \\
)\end{array}$ & $510(\mathrm{~m})$ & 375 \\
\hline 11 & $\begin{array}{l}{\left[\left(\mathrm{L}^{2}\right)_{2} \mathrm{Pd}\right]} \\
\mathrm{Cl}_{2} \cdot 2 \mathrm{H}_{2} \mathrm{O} \\
\end{array}$ & $\begin{array}{c}3403(\mathrm{~s} \\
\text { ) }\end{array}$ & & 3240(s) & 1605(s) & $1567(\mathrm{~s})$ & $500(\mathrm{~m})$ & 380 \\
\hline
\end{tabular}




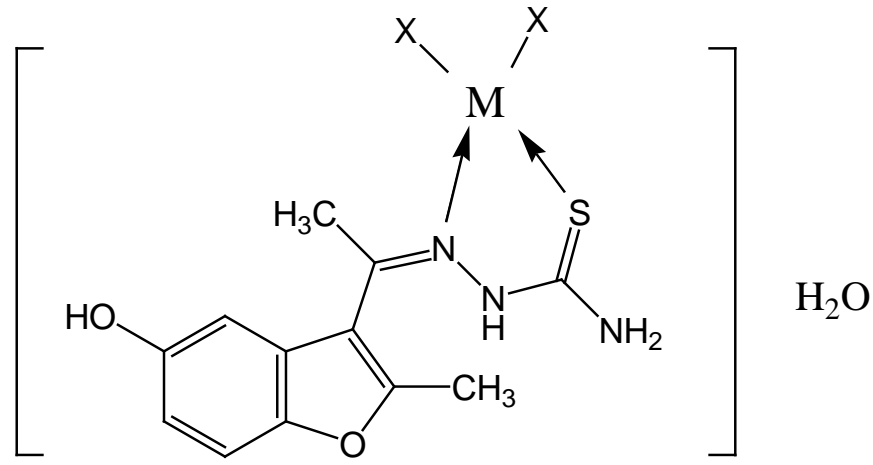

$\left[\mathrm{L} 1 \mathrm{MX}_{2}\right] \mathrm{H}_{2} \mathrm{O}$

M: $\mathrm{Cu}, \mathrm{Ni}$ or Pd

$\mathrm{X}$ : $\mathrm{Cl}$ in complexes 2, 4 and 5

$\mathrm{X}$ : Ac in complex 6

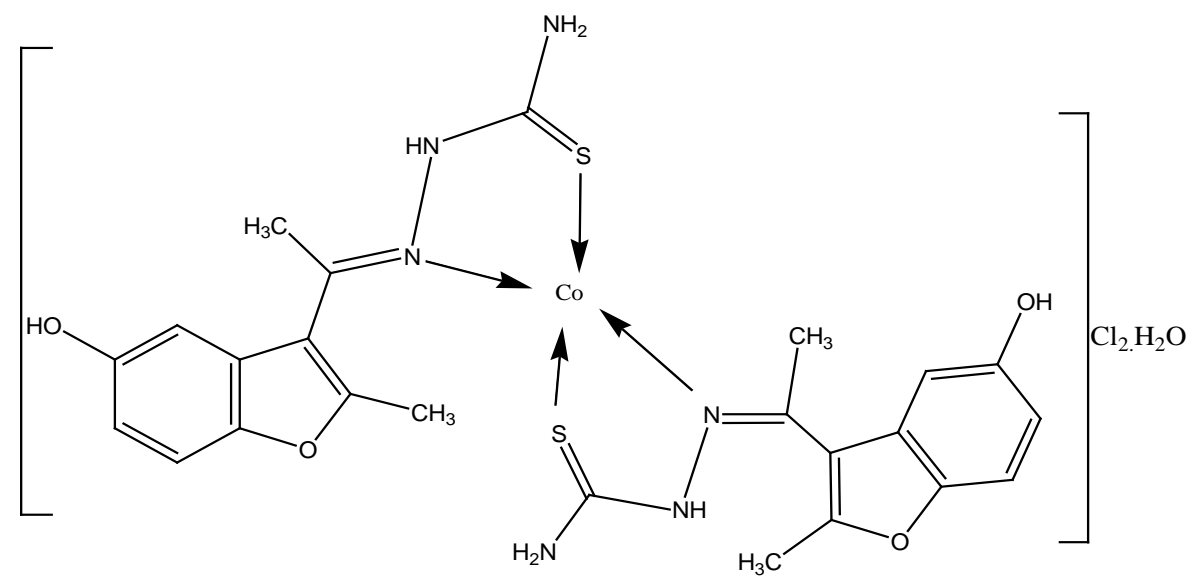

$\left[(\mathrm{L} 1)_{2} \mathrm{Co}\right] \mathrm{Cl}_{2} \mathrm{H}_{2} \mathrm{O}$

Complex 3

Figure 4. Structure of the complexes of the ligand $\mathrm{L}^{1}$

\section{Electronic Absorption Spectra and Magnetic Moment}

UV spectra of the thiosemicarbazone ligands $2 \mathbf{a}, \mathbf{b}\left(\mathrm{L}^{1}, \mathrm{~L}^{2}\right)$ and complexes, which were recorded in DMF, are summarized in Table 4. The free ligands show bands at 285,315 and $323,335 \mathrm{~nm}$ assigned to $\pi-\pi *$ and $\mathrm{n}-$ $\pi *$ of $\mathrm{C}=\mathrm{N}$ and $\mathrm{C}=\mathrm{S}$, respectively. The formation of complexes occurs through $(\mathrm{C}=\mathrm{S})$ thione form and $(\mathrm{C}=\mathrm{N})$ azomethine nitrogen. After complexation, $\lambda \max$ shifted to lower frequency/higher frequency depending upon the centre metal atom. Thus, the increase in intensity is attributed to extended conjugation in the ligands moiety after complexation. In the spectra 
of cobalt (II) complexes, the band observed at 357 and $350 \mathrm{~nm}$ may be assigned to C.T. of intraligand. The band which appears at 470 and $420 \mathrm{~nm}$ corresponds to $2 \mathrm{~B}_{2} \mathrm{~g}-2 \mathrm{~T}_{2} \mathrm{~g}$ electronic state and the magnetic moment value (3.5) B.M thereby indicating a square planar geometry (Kashar, 2010) for low spin $\mathrm{Co}^{2+}$ complex. The spectrum of Nickel (II) complex shows a band at $410 \mathrm{~nm}$ assigned to intraligand C.T. Also, the spectrum shows a band at 350 and $370 \mathrm{~nm}$ corresponding to $3 \mathrm{~A}_{2} \mathrm{~g}-3 \mathrm{~T}_{1} \mathrm{~g}$ electronic state transition. The magnetic moment value (2.4) indicates that the complex is present as tetrahedral arrangement (Lima et al., 1999). The copper(II) complex shows a band at 321,345,370 $\mathrm{nm}$ assigned to intraligand M-L C.T. and two bands at $440,410,415$ and $500,520 \mathrm{~nm}$ due to $\mathrm{d}-\mathrm{d}$ transitions assigned to $2 \mathrm{~B}_{1} \mathrm{~g}-2 \mathrm{~A}_{1} \mathrm{~g}$ and $2 \mathrm{~B}_{1} \mathrm{~g}-2 \mathrm{E}_{1} \mathrm{~g}$ electronic state. Thus, this indicates that the complex is formed in a square planar arrangement (Nishida \& Kida, 1979). The $\mu$ eff value (1.7) is around what is expected for the spin only value of one unpaired electron in the $\mathrm{d}^{9}$ copper ion. The palladium (II) complex shows a band at $400,410 \mathrm{~nm}$ assigned to intra-molecular charge transfer, and the diamagnetic character of the $\mathrm{Pd}^{2+}$ complex show the square planar geometry (Hammamm et al., 1988).

Table 4. UV Spectral data and (TG,DTA ) analysis of thiosemicarbazones ligands and their complexes

\begin{tabular}{|c|c|c|c|c|c|c|c|c|c|}
\hline \multirow{2}{*}{$\begin{array}{l}\mathrm{N} \\
\mathrm{o}\end{array}$} & \multirow[b]{2}{*}{$\begin{array}{c}\text { Compoun } \\
\mathrm{ds}\end{array}$} & \multicolumn{3}{|c|}{ UV Spectra $\chi_{\max }(\mathrm{nm})$} & \multicolumn{2}{|c|}{ TG Peaks } & \multicolumn{3}{|c|}{ DTA Peaks } \\
\hline & & $\begin{array}{l}\mathrm{n}- \\
\pi^{*}\end{array}$ & $\begin{array}{l}\pi- \\
\pi^{*}\end{array}$ & $\mathrm{C}-\mathrm{T}$ & Temp. ${ }^{\circ} \mathrm{C}$ & $\begin{array}{c}\text { wt lost } \\
\% \text { (calc.)fou } \\
\text { nd }\end{array}$ & Peak & $\begin{array}{l}\text { Temp. }^{\circ} \\
\text { C }\end{array}$ & Assignment \\
\hline 1 & $\begin{array}{c}\mathrm{L}^{1}\left(\mathrm{C}_{12} \mathrm{H}_{13}\right. \\
\left.\mathrm{N}_{3} \mathrm{O}_{2} \mathrm{~S}\right)\end{array}$ & 306 & 245 & - & $\begin{array}{l}111.1-231.6 \\
231.6-408.1 \\
408.1-630.7\end{array}$ & $\begin{array}{r}(12.2) 12.0 \\
(28.1) 27.5 \\
58.5\end{array}$ & $\begin{array}{l}\text { End } \\
\text { Exo. }\end{array}$ & $\begin{array}{l}198.2 \\
514.5\end{array}$ & $\begin{array}{c}\text { Loss of } \mathrm{NH}_{3}+\mathrm{CH}_{3} \\
\text { Loss of } \mathrm{C}=\mathrm{S} \text { NHNH } \\
\text { Thermal decomposition }\end{array}$ \\
\hline 2 & $\begin{array}{c}{\left[\mathrm{L}^{1} \mathrm{Cu}\right.} \\
\left.\mathrm{Cl}_{2}\right] \mathrm{H}_{2} \mathrm{O}\end{array}$ & 315 & 265 & $\begin{array}{c}370,4 \\
40,50 \\
2\end{array}$ & $\begin{array}{c}39.1-117.7 \\
117.7-298.7 \\
298.7-422 \\
422.1-631.9\end{array}$ & $\begin{array}{c}(4.5) 3.8 \\
(44.5) 44.5 \\
(14.8) 13.6 \\
61.1\end{array}$ & $\begin{array}{l}\text { Endo } \\
\text { Endo } \\
\text { Exo. }\end{array}$ & $\begin{array}{c}72.1 \\
229.2 \\
594.6\end{array}$ & $\begin{array}{c}\text { Loss of one lattice } \\
\text { water molecule } \\
\text { Loss of } \\
\mathrm{CL}_{2}+\mathrm{CH}_{3}+\mathrm{NH}_{3}+\mathrm{C}=\mathrm{SN} \\
\mathrm{HNH} \\
\text { Loss of } \mathrm{CO}_{2}+\mathrm{CH}_{3} \\
\text { Thermal decomposition }\end{array}$ \\
\hline 3 & $\begin{array}{c}{\left[\left(\mathrm{L}^{1}\right)_{2} \mathrm{Co}\right]} \\
\mathrm{Cl}_{2} \cdot \mathrm{H}_{2} \mathrm{O}\end{array}$ & $\begin{array}{c}320 \\
, 32 \\
6,\end{array}$ & 270 & $\begin{array}{l}470 \\
357\end{array}$ & $\begin{array}{c}19.3-99.5 \\
99.5-148.5 \\
148-183 \\
183-254.9 \\
254.9-596.8\end{array}$ & $\begin{array}{c}(9.9) 9.1 \\
(2.2) 3.2 \\
(5.4) 4.6 \\
(7.6) 7.0 \\
61.1\end{array}$ & $\begin{array}{l}\text { Endo } \\
\text { Endo } \\
\text { Endo } \\
\text { Exo. }\end{array}$ & $\begin{array}{c}43.6 \\
132.6 \\
178.9 \\
530.9\end{array}$ & $\begin{array}{c}\text { Loss of } \\
\mathrm{H}_{2} \mathrm{O}+2 \mathrm{NH}_{3}+\mathrm{CH}_{3} \\
\text { Loss of } \mathrm{CH}_{3} \\
\text { Loss of } \mathrm{HCl} \\
\text { Loss of } \mathrm{HCl}+\mathrm{CH}_{3} \\
\text { Thermal decomposition }\end{array}$ \\
\hline 4 & $\begin{array}{c}{\left[\mathrm{L}^{1} \mathrm{Ni}\right.} \\
\left.\mathrm{Cl}_{2}\right] \mathrm{H}_{2} \mathrm{O}\end{array}$ & 330 & $\begin{array}{c}289 \\
, 27 \\
9\end{array}$ & $\begin{array}{c}410,3 \\
70\end{array}$ & $\begin{array}{c}96.2-233.4 \\
233.4-348.2 \\
348.2-793.9\end{array}$ & $\begin{array}{c}(12.1) 11.0 \\
(24.1) 24.5 \\
49.9\end{array}$ & $\begin{array}{l}\text { Endo } \\
\text { Endo } \\
\text { Exo. }\end{array}$ & $\begin{array}{l}215.0 \\
293.3 \\
500.1\end{array}$ & $\begin{array}{c}\text { Loss of } \\
\mathrm{H}_{2} \mathrm{O}+\mathrm{NH}_{3}+\mathrm{CH}_{3} \\
\text { Loss of } \mathrm{Cl}_{2}+\mathrm{CO} \\
\text { Thermal decomposition }\end{array}$ \\
\hline 5 & $\begin{array}{c}{\left[\mathrm{L}^{1} \mathrm{Pd}\right.} \\
\left.\mathrm{Cl}_{2}\right] \mathrm{H}_{2} \mathrm{O}\end{array}$ & 310 & $\begin{array}{c}292 \\
, 27 \\
8\end{array}$ & 400 & $\begin{array}{c}11.5-191.4 \\
191.4-270.6 \\
270.6-363.4 \\
363.4-620.6 \\
620.6-\end{array}$ & $\begin{array}{l}(3.9) 2.7 \\
(6.5) 5.6 \\
(15.4) 14 \\
(9.6) 10.2 \\
5.9\end{array}$ & $\begin{array}{l}\text { Endo } \\
\text { Exo. } \\
\text { Endo }\end{array}$ & $\begin{array}{l}284.4 \\
411.6 \\
805.8\end{array}$ & $\begin{array}{c}\text { Loss of one lattice } \\
\text { water molecule } \\
\text { Lossof } 2 \mathrm{CH}_{3} \\
\text { Loss of } \mathrm{Cl}_{2} \\
\text { Loss of } \mathrm{CO}_{2}\end{array}$ \\
\hline
\end{tabular}




\begin{tabular}{|c|c|c|c|c|c|c|c|c|c|}
\hline & & & & & 1001.7 & & & & Thermal decomposition \\
\hline 6 & $\begin{array}{c}{\left[\mathrm{L}^{1} \mathrm{Cu}\right.} \\
\left.\mathrm{Ac}_{2}\right] \mathrm{H}_{2} \mathrm{O}\end{array}$ & 320 & $\begin{array}{c}289 \\
, 22 \\
6\end{array}$ & $\begin{array}{c}345,4 \\
10,52 \\
0\end{array}$ & $\begin{array}{c}25.7-121.7 \\
121.7-428.9 \\
428.9- \\
1000.2\end{array}$ & $\begin{array}{c}(4.0) 4.8 \\
(26.0) 27.4 \\
26.3\end{array}$ & $\begin{array}{l}\text { Exo. } \\
\text { Exo. } \\
\text { ExoE } \\
\text { xoEx } \\
\text { oExo }\end{array}$ & $\begin{array}{l}275.4 \\
360.8 \\
392.9 \\
696.8 \\
745.3 \\
773.9\end{array}$ & $\begin{array}{l}\text { Loss of one lattice } \\
\text { water molecule } \\
\text { Loss of } 2 \mathrm{CH}_{3} \mathrm{COOH} \\
\text { Thermal decomposition }\end{array}$ \\
\hline 7 & $\begin{array}{c}\mathrm{L}^{2}\left(\mathrm{C}_{16} \mathrm{H}_{15}\right. \\
\left.\mathrm{N}_{3} \mathrm{O}_{2} \mathrm{~S}\right)\end{array}$ & 310 & $\begin{array}{c}284 \\
, 28 \\
0\end{array}$ & - & $\begin{array}{c}10.8-241.7 \\
241.7-766.4 \\
766.4- \\
1000.2\end{array}$ & $\begin{array}{c}(10.2) 11.5 \\
(28.4) 28.7 \\
(8.27)\end{array}$ & $\begin{array}{c}\text { ExoE } \\
\text { хо. }\end{array}$ & $\begin{array}{l}510.9 \\
572.4\end{array}$ & $\begin{array}{c}\text { Loss of } \mathrm{CH}_{3}+\mathrm{NH}_{3} \\
\text { Loss of } \\
\text { C=SNHNH+CH}+\mathrm{CH}_{3} \\
\text { Thermal decomposition }\end{array}$ \\
\hline 8 & $\begin{array}{c}{\left[\mathrm{L}^{2} \mathrm{Cu}\right.} \\
\left.\mathrm{Cl}_{2}\right] \mathrm{H}_{2} \mathrm{O}\end{array}$ & $\begin{array}{c}310 \\
, 30 \\
0\end{array}$ & 287 & $\begin{array}{c}321,4 \\
15,50 \\
0\end{array}$ & $\begin{array}{c}25.6-146.1 \\
146.1-238.8 \\
238.8-383.5 \\
383.5-651.4 \\
651.4- \\
1001.9\end{array}$ & $\begin{array}{c}(3.9) 3.7 \\
(3.6) 4.5 \\
(35.2) 36.0 \\
10.9 \\
8.2\end{array}$ & $\begin{array}{l}\text { Exo. } \\
\text { Exo. } \\
\text { Exo. }\end{array}$ & $\begin{array}{l}241.3 \\
528.3 \\
986.8\end{array}$ & $\begin{array}{c}\text { Loss of one lattice } \\
\text { water molecule } \\
\text { Loss of } \mathrm{NH}_{3} \\
\text { Loss of } \\
\mathrm{Cl}_{2}+\mathrm{CH}_{3}+\text { Benzene } \\
\text { Thermal decomposition } \\
\text { Thermal decomposition }\end{array}$ \\
\hline 9 & $\begin{array}{c}{\left[\mathrm{L}^{2} \mathrm{Co}\right.} \\
\left.\mathrm{Cl}_{2}\right] 2 \mathrm{H}_{2} \mathrm{O}\end{array}$ & 318 & $\begin{array}{c}287 \\
, 27 \\
8\end{array}$ & $\begin{array}{l}420 \\
350\end{array}$ & $\begin{array}{c}17.5-71.7 \\
71.7-122.6 \\
122.6-214.2 \\
212.8-301.2 \\
301.2-512.4 \\
512.4-738.6 \\
738.6- \\
1000.4\end{array}$ & $\begin{array}{c}(7.5) 7.5 \\
(3.6) 4.4 \\
(7.6) 6.1 \\
(7.6) 6.8 \\
12.8 \\
15.2 \\
8.1\end{array}$ & $\begin{array}{l}\text { Endo } \\
\cdot \cdot \\
\text { Endo } \\
\cdot \cdot \\
\text { Exo. } \\
\text { Exo. }\end{array}$ & $\begin{array}{c}45.1 \\
126.9 \\
444.9 \\
\\
521.5\end{array}$ & $\begin{array}{c}\text { Loss of two lattice } \\
\text { water molecule } \\
\text { Loss of } \mathrm{NH}_{3} \text { molecules } \\
\text { Loss of } \mathrm{HC} \\
\text { Loss of HCl } \\
\text { Thermal decomposition } \\
\text { Thermal decomposition } \\
\text { Thermal decomposition }\end{array}$ \\
\hline $\begin{array}{l}1 \\
0\end{array}$ & $\begin{array}{c}{\left[\mathrm{L}^{2} \mathrm{Ni}\right.} \\
\left.\mathrm{Cl}_{2}\right] \mathrm{H}_{2} \mathrm{O}\end{array}$ & 320 & 270 & 350 & $\begin{array}{c}20.7-112.5 \\
112.5-202.4 \\
202.4-515.4 \\
517.3-997.1\end{array}$ & $\begin{array}{c}(11.8) \\
13.4 \\
(7.9) 7.2 \\
18.6 \\
23.5 \\
\end{array}$ & $\begin{array}{l}\text { Exo. } \\
\text { Exo. } \\
\text { Exo. } \\
\text { Exo. }\end{array}$ & $\begin{array}{c}63.1 \\
110.3 \\
427.8 \\
525.2\end{array}$ & $\begin{array}{c}\text { Loss of } \mathrm{H}_{2} \mathrm{O}+\mathrm{HCl} \\
\text { Loss of } \mathrm{HCl} \\
\text { Thermal decomposition } \\
\text { Thermal decomposition }\end{array}$ \\
\hline $\begin{array}{l}1 \\
1\end{array}$ & $\begin{array}{l}{\left[\left(\mathrm{L}^{2}\right)_{2} \mathrm{Pd}\right]} \\
\mathrm{Cl}_{2} \cdot 2 \mathrm{H}_{2} \mathrm{O}\end{array}$ & 345 & 280 & 410 & $\begin{array}{c}25.4-134.4 \\
134.4-215.9 \\
215.9-291.9 \\
291.9-439.8 \\
439.9-705 \\
705.0- \\
1000.3\end{array}$ & $\begin{array}{c}(4.3) 5.3 \\
(6.4)) 6.4 \\
(16.9) 17.9 \\
10.9 \\
12.5 \\
10.3\end{array}$ & $\begin{array}{l}\text { Exo. } \\
\text { Exo. } \\
\text { Exo. }\end{array}$ & $\begin{array}{l}373.1 \\
390.6 \\
414.8\end{array}$ & $\begin{array}{c}\text { Loss of } 2 \mathrm{H}_{2} \mathrm{O} \\
\text { Loss of } \mathrm{HCl}+\mathrm{NH}_{3} \\
\text { Loss of } \\
\mathrm{HCl}+\mathrm{NH} 3+2 \mathrm{CO}_{2} \\
\text { Thermal decomposition } \\
\text { Thermal decomposition } \\
\text { Thermal decomposition }\end{array}$ \\
\hline
\end{tabular}

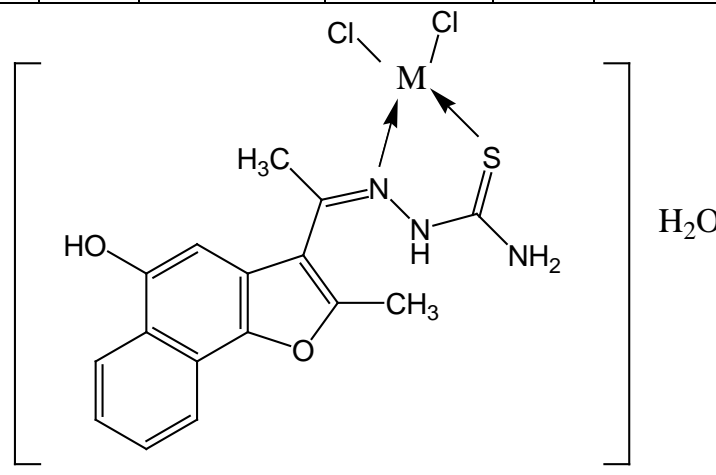

$$
\left[\mathrm{L} 2 \mathrm{MCl}_{2}\right] \mathrm{H}_{2} \mathrm{O}
$$

$\mathrm{M}: \mathrm{Cu}, \mathrm{Co}$ or $\mathrm{Ni}$

complexes 8,9 and 10 

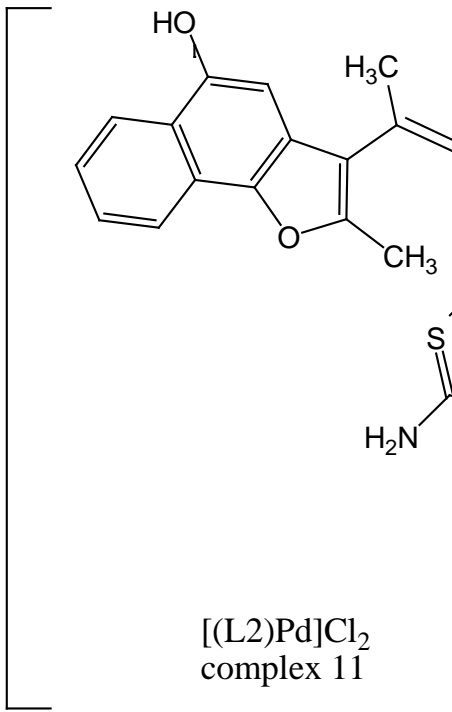<smiles>C[Te]1(C)NNC(N)=[SH]1</smiles>

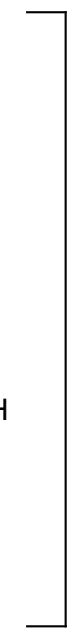

$\mathrm{Cl}_{2}$

[(L2)Pd]Cl ${ }_{2}$ complex 11

Figure 5. Structure of the complexes of the ligand $\mathrm{L}^{2}$

\section{DTA and TGA Thermal Analyses}

Thiosemicarbazone ligand $\mathbf{2 a}\left(\mathbf{L}^{\mathbf{1}}\right)$ shows endothermic peak at $198.2^{\circ} \mathrm{C}$ with weight loss of $12.2 \%$ due to the loss of $\mathrm{NH}_{3}+\mathrm{CH}_{3}$. Also, it shows another exothermic peak at $514.5^{\circ} \mathrm{C}$ due to loss of $\mathrm{C}=\mathrm{S} \mathrm{NHNH}$ with weight loss of $28.1 \%$ followed by further decomposition. The results of the thermogravimetric analysis of the metal complexes under study Table 4 shows that the complexes lost their lattice water only or with $\mathrm{NH}_{3}$ and $\mathrm{CH}_{3}$ below $200^{\circ} \mathrm{C}$. The anhydrous complexes lost the chloride moiety at the temperature above $200^{\circ} \mathrm{C}$ and then displayed the decomposition of the organic ligand within the temperature range from $400-800^{\circ} \mathrm{C}$ leading to the formation of the metal oxides (Lever, 1984).

The following reactions represent the steps of thermal decomposition. $\mathrm{MLCl}_{\mathrm{x}} \cdot \mathrm{nH}_{2} \mathrm{O} \rightarrow[\mathrm{MLCl}] \rightarrow \mathrm{ML}$

$\mathrm{ML} \rightarrow \mathrm{MO}_{2}$

The first step with TGA peak in the $25-190{ }^{\circ} \mathrm{C}$ range represented the loss of the lattice water molecule only or with $\mathrm{NH}_{3}$ and $\mathrm{CH}_{3}$. In most complexes, an endothermic peak occurs due to the loss of chloride moieties from the metal complexes. In the third step of decomposition, the organic ligand is lost in the temperature range from $254-800^{\circ} \mathrm{C}$ with the formation of stable metal oxides (Tahani \& Amal, 2013; Tahani, 2013).

\section{Linear Polarization Resistance (LPR) and Galvanic Corrosion}

LPR measurements are most effective in aqueous solutions, and it has been proven to be a rapid response technique. Due to the widespread 
corrosion of reinforcing materials in acidic media, there has been a concerted demand for the development of non-destructive techniques to enable accurate assessment of the condition of structures in aggressive solution. LPR monitoring has been developed to address this need. The polarization resistance is the ratio of the applied potential and the resulting current level (Ohm low). Furthermore, the measured resistance is inversely related to the corrosion rate. Thus, the electrical resistance of any conductor is given by eq. (1):

$$
R=\frac{V}{I}
$$

Where, $\mathrm{R}$ is effective instantaneous resistance, $\mathrm{V}$ is applied voltage, and $\mathrm{I}$ is instantaneous current between electrodes.

In order to determine the corrosion current density, $\mathrm{i}_{\text {corr }}$, the surface area, A, of cast iron that has been polarized needs to be accurately known: $\mathrm{i}_{\text {corr }}=\mathrm{I}_{\text {corr }} / \mathrm{A}$.

When the electrodes will be corroding at a high rate, the metal ions passes easily into solution. This means a small potential applied between the electrodes will produce a high current, resulting to a low polarization resistance. This corresponds to a high corrosion rate. Linear polarization resistance (LPR) carves were determined in the absence and presence of tow thiosemicarbazones $\mathbf{2 a}\left(\mathbf{L}^{\mathbf{1}}\right)$ and $\mathbf{2} \mathbf{b}\left(\mathbf{L}^{2}\right)$ as shown in Figure 6. The effect of thiosemicarbazones concentration on the slope of polarization resistance lines in $1.0 \mathrm{M} \mathrm{H}_{2} \mathrm{SO}_{4}$ was used to calculate the corrosion rate (CR) as shown in Table 5. Furthermore, it has been observed that when inhibitor is introduced into the test environment, LPR values increases and corrosion rate decreases. The $\mathrm{CR}(\mathrm{mpy})$ decreased from $1232 \mathrm{mmpy}$ to $187.2 \mathrm{mpy}$ and 250.1mpy for $\mathbf{2} \mathbf{a}\left(\mathbf{L}^{\mathbf{1}}\right)$ and $\mathbf{2} \mathbf{b}\left(\mathbf{L}^{\mathbf{2}}\right)$, respectively. The inhibition efficiency Inh\% calculated by eq.(2) were found to increase with increasing thiosemicarbazones concentration up to $84.81 \%$ and $79.96 \%$ at $5 \times 10^{-3} \mathrm{M}$ of $\mathbf{2 a}\left(\mathbf{L}^{\mathbf{1}}\right)$ and $\mathbf{2} \mathbf{b}\left(\mathbf{L}^{\mathbf{2}}\right)$ thiosemicarbazones, respectively.

$$
\text { Inh. } \%=\frac{\mathrm{CR}^{\circ}-\mathrm{CR}}{\mathrm{CR}^{\circ}} \times 100
$$

Galvanic current experiments were performed in the absence and presence of $\mathbf{2} \mathbf{a}\left(\mathbf{L}^{\mathbf{1}}\right)$ and $\mathbf{2} \mathbf{b}\left(\mathbf{L}^{2}\right)$ thiosemicarbazones with time. The average Galvanic current densities, (i $\left.i_{\text {gal }}\right)$ and Inh\%, calculated by eq.(3) are summarized in Table 5.

$$
\text { Inh. } \%=\frac{\text { Avri }_{\text {gal }}{ }^{\circ}-\mathrm{Avri}_{\text {gal }}}{\mathrm{Avri}_{\text {gal }}{ }^{\mathrm{o}}} \times 100
$$

Subsequently, the addition of different concentration of studied thiosemicarbazones inhibitors reduce the corrosion rate by the reduction of 


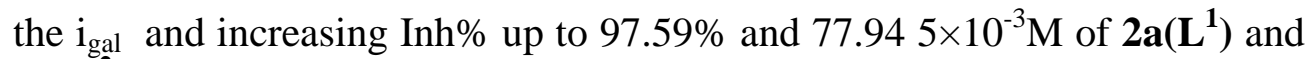
$\mathbf{2 b}\left(\mathbf{L}^{2}\right)$, respectively. Thus, the galvanic current distribution was in good agreement with LPR measurements.

\section{Electrochemical Methods}

Electrochemical impedance is a powerful technique used for the investigation of corrosion inhibition and adsorption phenomena (Badawy, 2014). It is a rapid, nondestructive, and in situ measurements of the kinetic state of a conduction surface in electrolytic environments. Consequently, impedances must be measured at very low frequencies, usually far below $1 \mathrm{~Hz}$, in order to get meaningful faradaic information. Also, it does not disturb the electrode properties to be measured. Figure 7 (a \& b) shows the data of cast iron as a function of thiosemicarbazones $\mathbf{2 a}\left(\mathbf{L}^{\mathbf{1}}\right)$ and $\mathbf{2} \mathbf{b}\left(\mathbf{L}^{2}\right)$ concentrations, respectively. The curves show a similar type of Nyquist plot of one time contestant with depressed semicircles at the center below the real x-axis. The roughness of the electrode surface leads to this characteristic for electrode/solution interface. It is evident from Figure 7 that the impedance response of cast iron in $1.0 \mathrm{M} \mathrm{H}_{2} \mathrm{SO}_{4}$ has been significantly altered after the addition of Schiff base into the test media. The depressed semicircles' sizes were increased by raising the thiosemicarbazones concentration. As a result, it indicates the reduction of the charge transfer presses on the cast iron. A similar mechanism of inhibition was also suggesting due to the same style of the impedance curve at all inhibitor concentrations. To determine the impedance parameters, Table 5 which shows the impedance data were analyzed based on the electric equivalent circuit presented in Figure 8. This circuit consists of the resistance of solution (Rs) between the working electrode and the counter electrode, and the double-layer capacitance $\left(\mathrm{C}_{\mathrm{dl}}\right)$ in parallel to the charge-transfer resistance $\left(\mathrm{R}_{\mathrm{ct}}\right)$. Thus, this takes into account the deviation of the double layer behavior from the ideal capacitance due to surface in homogeneity (Jiittner et al., 1985). Also, very good fit to the equivalent circuit model was obtained as shown in Figure 8 in solid line. In such circuit, CPE is the constant phase element with an admittance given by eq.(4):

$$
Z_{C P E}=Q^{-1}\left[(j \omega)^{n}\right]^{-1}
$$

where $\mathrm{j}^{2}=-1, \omega$ is the sine wave modulation angular frequency, $\mathrm{Q}$ is the base admittance (CPE), and $n$ is an empirical exponent that usually lies between 0.50 and 1.0. The inhibition efficiency of thiosemicarbazones $\mathbf{2 a}\left(\mathbf{L}^{\mathbf{1}}\right)$ and $\mathbf{2 b}\left(\mathbf{L}^{2}\right)$ was evaluated by $\mathrm{R}_{\mathrm{ct}}$ of the impedance according to eq.5. 


$$
\text { Inh. } \%=\frac{R_{c t}{ }^{0}-R_{\mathrm{ct}}}{R_{c t}{ }^{0}} \times 100
$$

where $\mathrm{R}_{\mathrm{ct}}{ }^{0}$ and $\mathrm{R}_{\mathrm{ct}}$ are the charge transfer resistance values without and with thiosemicarbazones $\mathbf{2 a}\left(\mathbf{L}^{\mathbf{1}}\right)$ and $\mathbf{2} \mathbf{b}\left(\mathbf{L}^{2}\right)$, respectively.

Fitting results are listed in Table 5 as a function of each thiosemicarbazone concentration. The larger the diameter of the semicircle, the more densely packed the inhibitor layer. Thus, this result to a higher $\mathrm{R}_{\mathrm{ct}}$ and lower CPE values. The large $\mathrm{R}_{\mathrm{ct}}$ is associated with a slower corrosion system. The increase of $\mathrm{n}$ values with hiosemicarbazones concentration reviles the decrease in surface heterogeneity due to the adsorption of the inhibitor on the most active adsorption sites (Benedetti, 1995). The value of CPE decreases on addition of thiosemicarbazones. Therefore, this indicates a decrease in the local dielectric constant and/or an increase in the thickness of the electrical double layer. This, however, suggests that the inhibitor molecule functions by formation of the protective layer at the cast iron surface.

Table 5. Corrosion parameters and the corresponding inhibition efficiency for cast iron in

$1.0 \mathrm{M} \mathrm{H}_{2} \mathrm{SO}_{4}$ in absence and presence of different concentration of thiosemicarbazones

\begin{tabular}{|c|c|c|c|c|c|c|c|c|c|c|c|c|}
\hline \multirow[t]{2}{*}{$\begin{array}{l}\text { inhib } \\
\text { itor }\end{array}$} & \multirow[t]{2}{*}{$\mathrm{C}_{\text {Inh. }}$} & \multicolumn{4}{|c|}{ EIS } & \multicolumn{3}{|c|}{ Potent dynamic } & \multicolumn{2}{|c|}{$\begin{array}{c}\text { Galvanic } \\
\text { corrosion } \\
\text { measurement } \\
\mathrm{s}\end{array}$} & \multicolumn{2}{|c|}{$\begin{array}{c}\text { Polarization } \\
\text { resistance } \\
\text { measurements }\end{array}$} \\
\hline & & $\begin{array}{c}\text { Rct } \\
\Omega_{2} \mathrm{~cm} \\
\end{array}$ & $\begin{array}{l}\mathrm{CPE} \\
\left(\mathrm{m} \Omega^{-}\right. \\
\left.{ }^{1} \mathrm{Cm}^{-2}\right) \\
\end{array}$ & $n$ & $\begin{array}{c}\text { Inh. } \\
\%\end{array}$ & $\begin{array}{c}\mathrm{I}_{\text {corr }}( \\
\mathrm{mA} / \mathrm{c} \\
\left.\mathrm{m}^{2}\right)\end{array}$ & $\begin{array}{c}-E_{\text {corr }} \\
(\mathrm{mV})\end{array}$ & $\begin{array}{c}\text { Inh. } \\
\%\end{array}$ & $\begin{array}{l}\mathrm{i}(\mathrm{mA} \\
\left./ \mathrm{cm}^{2}\right)\end{array}$ & $\begin{array}{c}\text { Inh. } \\
\%\end{array}$ & $\begin{array}{c}\text { CR(mpy } \\
\text { ) }\end{array}$ & $\begin{array}{c}\text { Inh. } \\
\%\end{array}$ \\
\hline \multirow{5}{*}{$\underset{\mathbf{1}}{2 \mathrm{a}(\mathrm{L}}$} & Blank & $\begin{array}{c}6.57 \\
6\end{array}$ & $\underset{3}{3.08 \times 10^{-}}$ & 0.818 & - & 2.120 & 455 & - & 26.41 & & 1232 & - \\
\hline & $10-4$ & $\begin{array}{c}11.5 \\
5\end{array}$ & $\begin{array}{c}2.33 \times 10^{-} \\
3\end{array}$ & 0.718 & 43.06 & 1.15 & 446 & 45.75 & 09.37 & $\begin{array}{c}58.2 \\
6\end{array}$ & 538.1 & 56.32 \\
\hline & $\begin{array}{c}5 \times \\
10-4\end{array}$ & $\begin{array}{c}14.7 \\
9\end{array}$ & $\underset{3}{2.45 \times 10^{-}}$ & 0.773 & 55.54 & 1.05 & 450 & 51.88 & 07.44 & $\begin{array}{c}68.2 \\
1\end{array}$ & 438.9 & 64.37 \\
\hline & $10-3$ & $\begin{array}{c}30.7 \\
1\end{array}$ & $\underset{3}{1.80 \times 10^{-}}$ & 0.646 & 78.59 & 0.516 & 463 & 75.66 & 01.60 & $\begin{array}{c}93.1 \\
6\end{array}$ & 306.4 & 75.13 \\
\hline & $\begin{array}{c}5 \times \\
10-3 \\
\end{array}$ & $\begin{array}{c}62.9 \\
1 \\
\end{array}$ & $\begin{array}{c}1.37 \times 10^{-} \\
3\end{array}$ & 0.656 & 89.54 & $\begin{array}{r}268 \times \\
10^{-3} \\
\end{array}$ & 468 & 87.35 & $\begin{array}{r}563 \times \\
10^{-3} \\
\end{array}$ & $\begin{array}{c}97.5 \\
9 \\
\end{array}$ & 187.2 & 84.81 \\
\hline \multirow{4}{*}{$\underset{2}{2 b(L}$} & $10-4$ & $\begin{array}{c}9.87 \\
9\end{array}$ & $\underset{3}{2.33 \times 10^{-}}$ & 0.731 & 33.4 & 1.45 & 460 & 31.60 & 14.75 & 44.1 & 593.7 & 51.81 \\
\hline & $\begin{array}{c}5 \times \\
10-4\end{array}$ & $\begin{array}{c}13.3 \\
8\end{array}$ & $\underset{3}{2.45 \times 10^{-}}$ & 0.655 & 50.85 & 1.10 & 469 & 48.11 & 13.25 & $\begin{array}{c}49.8 \\
1\end{array}$ & 360.6 & 70.07 \\
\hline & $10-3$ & $\begin{array}{c}15.5 \\
1\end{array}$ & $\underset{3}{1.80 \times 10^{-}}$ & 0.772 & 57.60 & 0.988 & 454 & 53.34 & 9.84 & $\begin{array}{c}62.7 \\
1\end{array}$ & 283.6 & 76.98 \\
\hline & $\begin{array}{c}5 \times \\
10-3\end{array}$ & $\begin{array}{c}17.4 \\
4\end{array}$ & $\begin{array}{c}1.37 \times 10^{-} \\
3\end{array}$ & 0.892 & 62.22 & 0.823 & 459 & 61.12 & 5.02 & $\begin{array}{c}77.9 \\
4\end{array}$ & 250.1 & 79.96 \\
\hline
\end{tabular}



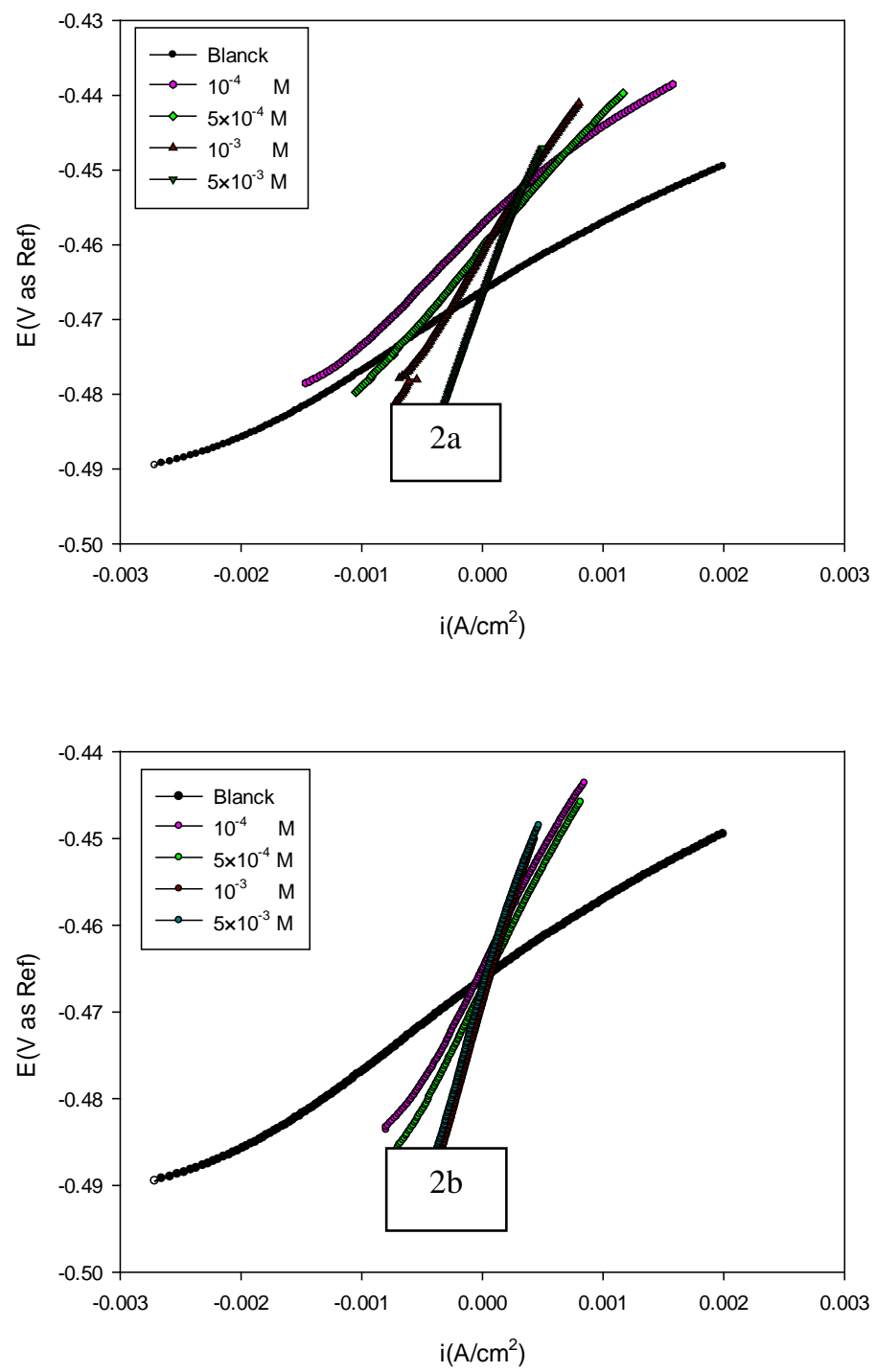

Figure 6. Potential vs current density for cast iron in $1.0 \mathrm{M} \mathrm{H}_{2} \mathrm{SO}_{4}$ in absence and presence of different concentration of thiosemicarbazones $2 \mathrm{a}\left(\mathrm{L}^{1}\right)$ and $2 \mathrm{~b}\left(\mathrm{~L}^{2}\right)$ 

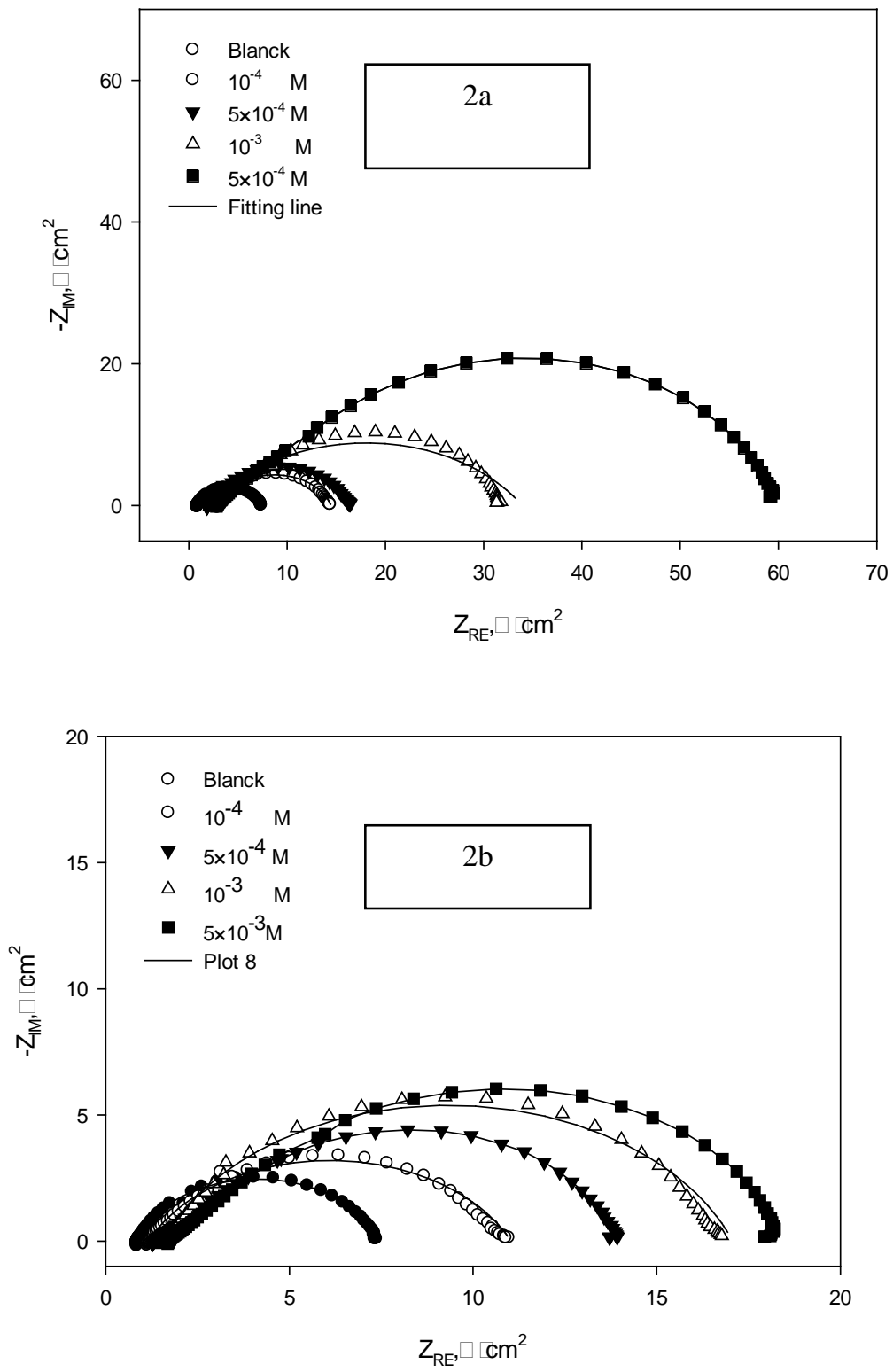

Figure 7. Nyquist impedance spectra recorded for cast iron in $1.0 \mathrm{M} \mathrm{H}_{2} \mathrm{SO}_{4}$ solution as a function of the concentration of thiosemicarbazones $2 a\left(\mathrm{~L}^{1}\right)$ and $2 \mathrm{~b}\left(\mathrm{~L}^{2}\right)$.

It has been found that the addition of thiosemicarbazones $\mathbf{2 a}\left(\mathbf{L}^{\mathbf{1}}\right)$ and $\mathbf{2 b}\left(\mathbf{L}^{2}\right)$ enhance the inhibition efficiency. Also, the extent of corrosion inhibition depends on the concentration and structure of thiosemicarbazones $\mathbf{2 a}\left(\mathbf{L}^{1}\right)$ and $\mathbf{2 b}\left(\mathbf{L}^{2}\right)$. 
Potentiodynamic measurements were made after EIS studies in the same cell set of $\mathbf{2 a}\left(\mathbf{L}^{\mathbf{1}}\right)$ and $\mathbf{2} \mathbf{b}\left(\mathbf{L}^{2}\right)$ thiosemicarbazones concentrations, respectively. The anodic and cathodic pranges in Figure 9 reveal that the presence of the thiosemicarbazones inhibits both anodic dissolution and hydrogen evolution as mixture inhibitor. The cathodic reaction is more profound in the presence of $\mathbf{2} \mathbf{b}\left(\mathbf{L}^{2}\right)$ as shown in Figure 9. Furthermore, it is known that the cathodic reaction is the rate determent reaction in corrosion process. As a result, it leads to more impairing of this reaction, and more reducing of corrosion presence. The corrosion current densities were calculated from the polarization curves by extrapolation of the linear logarithmic segments of the anodic and cathodic Tafel lines to the point of intersection. The corrosion current density ( $\mathrm{i}_{\text {corr }}$ ) data are used to calculate the inhibition efficiency according to eq. (6).

$$
\text { Inh. } \%=\frac{i_{\text {corr }}{ }^{\circ}-i_{\text {corr }}}{i_{\text {corr }}{ }^{\circ}} \times 100
$$

Inspection of Table 5 reveals that corrosion current densities $\left(\mathrm{i}_{\text {corr }}\right)$ in the presence of $\mathbf{2 a}\left(\mathbf{L}^{1}\right)$ and $\mathbf{2} \mathbf{b}\left(\mathbf{L}^{2}\right)$ thiosemicarbazones were decreased notably compared to uninhibited media. Corrosion current densities for the $\mathbf{2 a}\left(\mathbf{L}^{\mathbf{1}}\right)$ inhibitor decreases more than $2 \mathrm{~b}\left(\mathbf{L}^{2}\right)$ system. This inhibition efficiency order can be readily explained in terms of their molecular structure. Considering the molecular structure of the inhibitors, both inhibitors contains $\mathrm{C}=\mathrm{N}$ and $\mathrm{C}=\mathrm{S}$ coordination gropes. These polar units are regarded as the reaction centre for the adsorption process. The five member ring is not involved in the adsorption processes. This result is due to the presence of oxygen atom which decreases the localization of lone pair of electrons for adsorption. The compound $\mathbf{2 a}\left(\mathbf{L}^{\mathbf{1}}\right)$ contain an extra six member ring. Adsorption of the compound on metal surface is supported by the high donation of $\pi$-electron present in six member ring. So, it can be seen that $\mathbf{2 a}\left(\mathbf{L}^{\mathbf{1}}\right)$ has the propensity of covering a higher surface area as well as having the highest number of $\pi$-electrons in its structure. Thus, it is well known that the higher the surface coverage by the inhibitor molecule, the higher will be the inhibition efficiency. Finally, we can conclude that the type of adsorption of $\mathbf{2 a}\left(\mathbf{L}^{1}\right)$ and $\mathbf{2 b}\left(\mathbf{L}^{2}\right)$ on cast iron surface is a combination of electrostatic attraction between the charged molecules and the charged metal with the interaction of $\pi$-electrons with the metal.

Subsequently, the EFM technique is capable of measuring a corrosion rate without prior knowledge of the Tafel parameters with only a small polarizing signal and within a reasonable time. This technique is an ideal candidate for on-line corrosion monitoring applications. Thus, it is used to confirm EIS and polarization measurements. Figure 10 shows the corresponding current response in the frequency spectrum for cast iron as a 
faction of $\mathbf{2 a}\left(\mathbf{L}^{\mathbf{1}}\right)$ and $\mathbf{2} \mathbf{b}\left(\mathbf{L}^{2}\right)$ concentrations, respectively. The harmonic and intermodulation peaks are clearly seen and are much larger than the background noise. Corrosion rates mmpy and other kinetic parameters ( $\mathrm{i}_{\text {corr }}$, $\mathrm{b}_{\mathrm{a}}, \mathrm{b}_{\mathrm{c}}$, , GF-2 , Gf-3 and Inh. \%) obtained by EFM-technique was estimated in Table 6 . The results compared with corrosion rates were obtained from more established techniques like LPR, Tafel-extrapolation, and Galvanic measurements. The causality factor 2 (eq.7) is equal to two, and the causality factor 3 (eq.8) is equal to three if there is a relation between the perturbation signal and the distorted response signal. Thus, the idea behind this causality factor is that it can be used to check the validity of the data. If the causality factors differ significantly from the theoretical values of two and three, it can be deduced that the measurements are influenced by noise (ElDesoky et al., 2015).

Causality factor $2(\mathrm{GF}-2)=\frac{i_{\omega 2 \pm \omega 1}}{i_{2 \omega 1}}=2.0$

Causality factor $3(\mathrm{GF}-3)=\frac{i_{2 \omega 2 \pm \omega 1}}{i_{3 \omega 1}}=3.0$

Inspection of data in Table 6 infer the following: (1) the addition of $\mathbf{2 a}\left(\mathbf{L}^{1}\right)$ and $\mathbf{2} \mathbf{b}\left(\mathbf{L}^{2}\right)$ decease the corrosion rate (i $\mathrm{i}_{\text {corr }}$ and mmpy); (2) increase thiosemicarbazones concentration lead to a rise in the Inh.\% (calculated by eq. 6 using $\mathrm{i}_{\text {corr }}$ from EFM technique) up to $81.81 \%$ and $60.54 \%$ at $5 \times 10-{ }^{3} \mathrm{M}$ of $\mathbf{2 a}\left(\mathbf{L}^{1}\right)$ and $\mathbf{2} \mathbf{b}\left(\mathbf{L}^{2}\right)$, respectively. This result to increasing adsorption and surface coverage of thiosemicarbazones on cast iron; (3) the causality factors are approximately equal to the predicted values of two and three. This means there is a causal relation between the perturbation signal and the response signal. As such, the data is assumed to be reliable. Furthermore, these findings are clearly supported by electrochemical measurements and LPR, Galvanic measurements.

Table 6. EFM data for electrochemical kinetic parameters for cast iron in $1.0 \mathrm{M} \mathrm{H}_{2} \mathrm{SO}_{4}$ in absence and presence of different concentration of thiosemicarbazones

\begin{tabular}{|c|c|c|c|c|c|c|c|c|c|}
\hline & \multicolumn{9}{|c|}{ EFM at $0.1 \mathrm{~Hz}$} \\
\hline & \multirow{2}{*}{ blank } & \multicolumn{4}{|c|}{$2 \mathrm{a}\left(\mathbf{L}^{\mathbf{1}}\right)$} & \multicolumn{4}{|c|}{$2 b\left(\mathbf{L}^{2}\right)$} \\
\hline & & $10-4$ & $\begin{array}{l}5 \times \\
10^{-4}\end{array}$ & $10^{-3}$ & $\begin{array}{l}5 \times \\
10^{-3}\end{array}$ & $10^{-4}$ & $\begin{array}{l}5 \times \\
10^{-4}\end{array}$ & $10^{-3}$ & $\begin{array}{l}5 \times \\
10^{-3}\end{array}$ \\
\hline $\mathrm{i}_{\mathrm{corr}}(\mu \mathrm{A} / \mathrm{cm} 2)$ & 310.5 & 189.2 & 142.6 & 70.26 & 56.5 & 214.9 & 153.6 & 138.7 & 122.5 \\
\hline$\beta a(V /$ decay $)$ & 0.32 & 0.34 & 0.35 & 0.39 & 0.45 & 37.9 & 0.47 & 0.41 & 0.37 \\
\hline$\beta \mathrm{c}(\mathrm{V} / \mathrm{decay})$ & 0.34 & 0.38 & 0.41 & 0.38 & 0.39 & 39.29 & 0.49 & 0.45 & 0.42 \\
\hline $\begin{array}{l}\text { Corrosion rate } \\
\text { (mpy) }\end{array}$ & 146.9 & 97.8 & 72.9 & 41.4 & 28.0 & 106.0 & 70.3 & 66.2 & 58.7 \\
\hline $\mathrm{CF}(2)$ & 1.777 & 1.277 & 1.790 & 2.200 & 1.8 & 1.366 & 1.94 & 2.1 & 1.9 \\
\hline $\mathrm{CF}(3)$ & 2.401 & 2.517 & 2.580 & 3.1 & 2.3 & 2.167 & 2.587 & 3.1 & 2.577 \\
\hline Inh. $i_{\text {corr }} \%$ & - & 39.07 & 54.07 & 77.37 & 81.81 & 30.78 & 50.53 & 55.33 & 60.54 \\
\hline
\end{tabular}




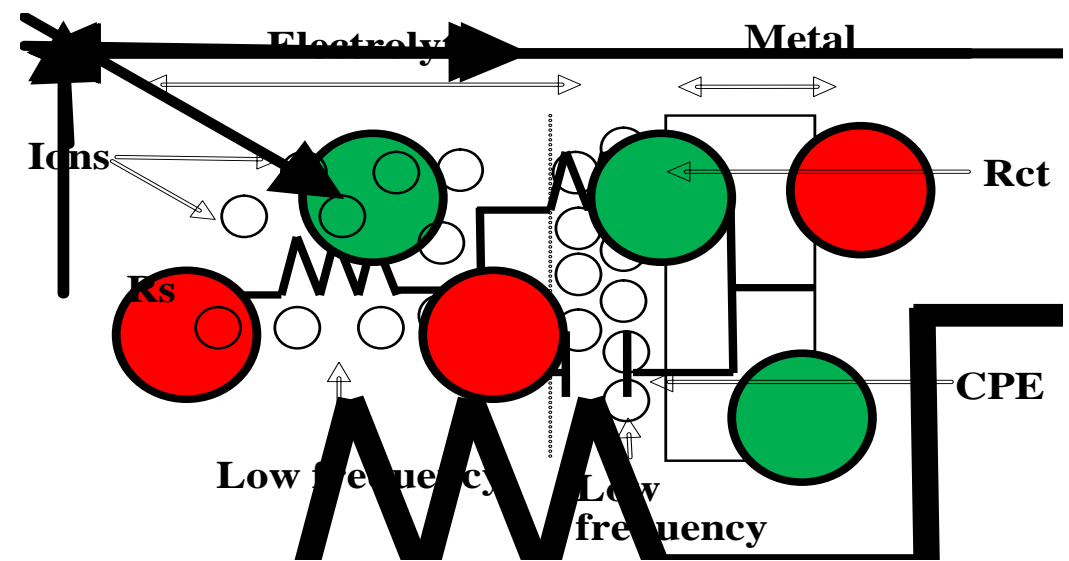

Figure 8. The Randles CPE circuit which is the equivalent circuit for this impedance spectra
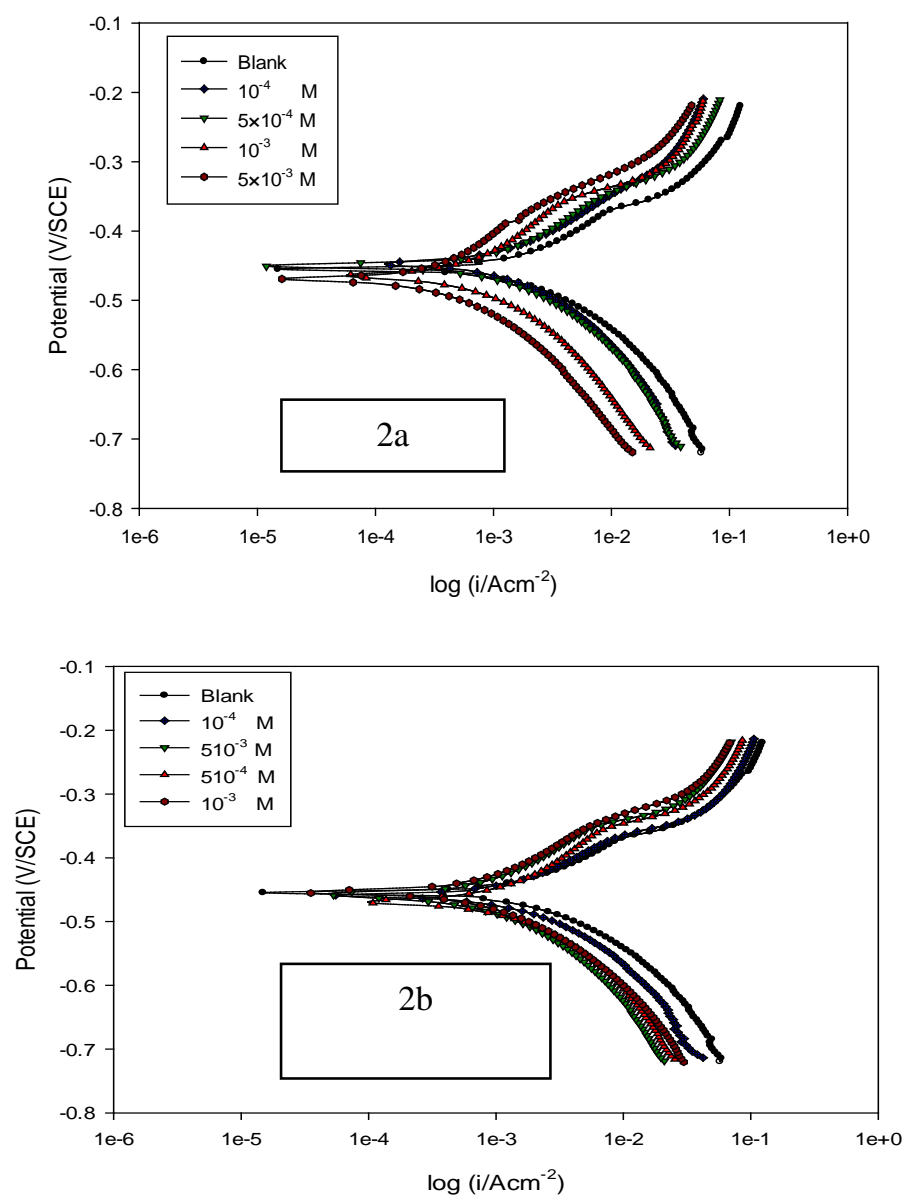
Figure 9. Anodic and cathodic polarization curve for cast iron in $1.0 \mathrm{M} \mathrm{H}_{2} \mathrm{SO}_{4}$ solution as a function of concentration of thiosemicarbazones $2 a\left(\mathrm{~L}^{1}\right)$ and $2 \mathrm{~b}\left(\mathrm{~L}^{2}\right)$
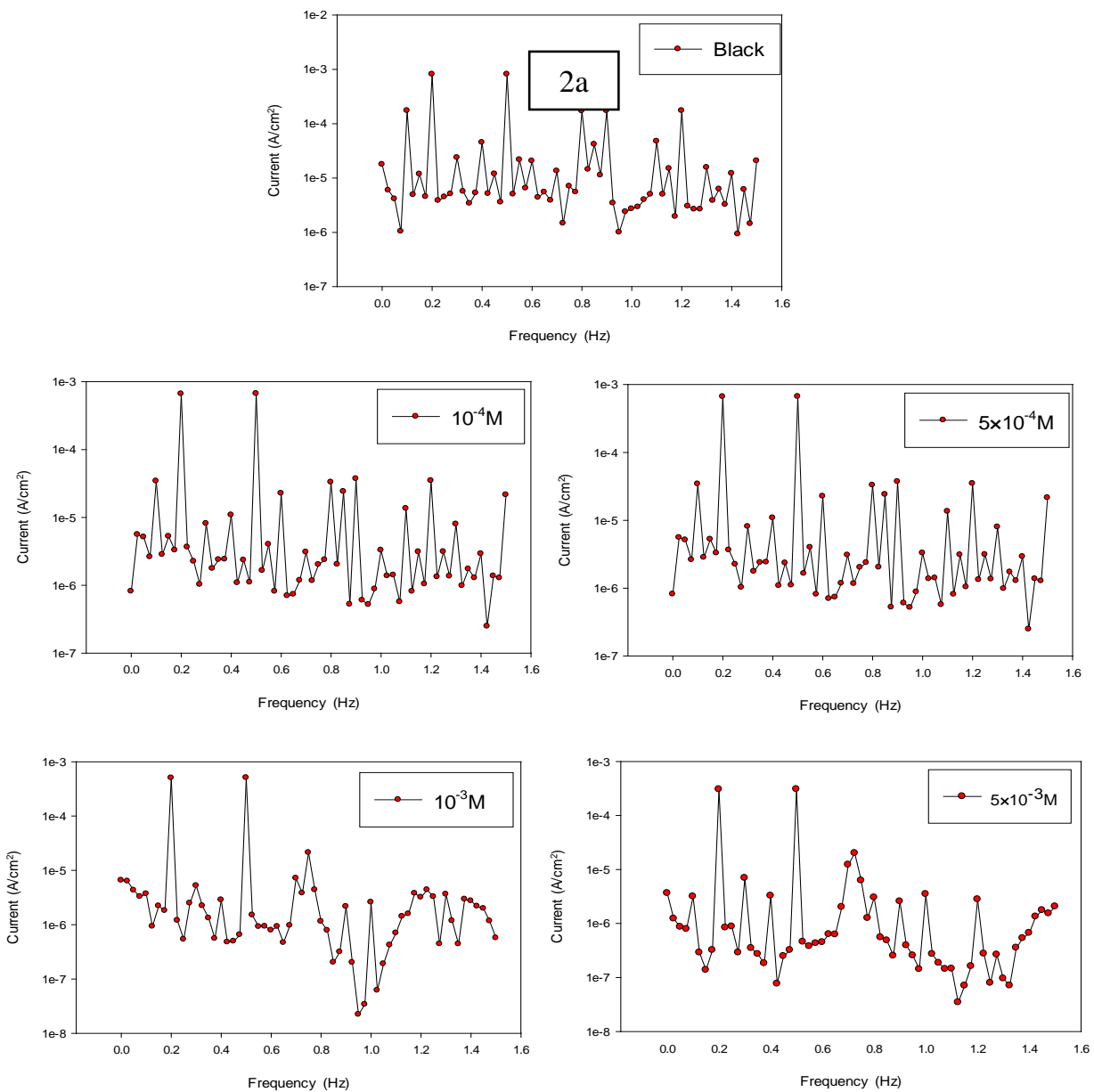

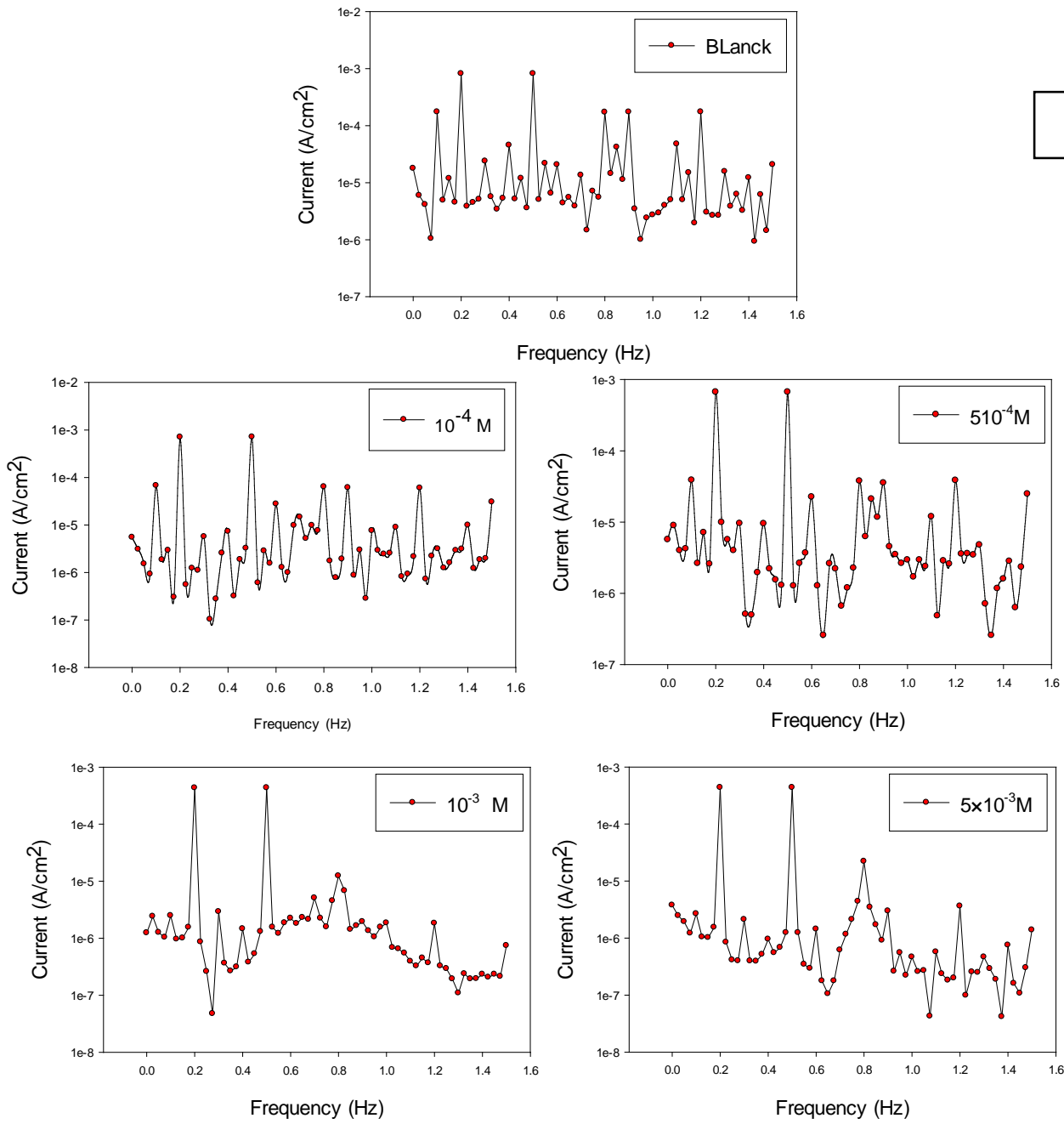

Fig. 10. Current I vs. frequency f plots for cast iron in 1.0M H2SO4 solution as function

\section{Biological Activity}

The biological activities of the ligand and their metal complexes (Cu(II), Ni(II), Co(II), and $\mathrm{Pd}(\mathrm{II})$ ) were screened for antibacterial activity against $E$. coli and $S$. aureus and for antifungal activity against $A$. flavus and C. albicans. Ampicillin trihydrate for bacteria and Amphotericin B for fungi were used as reference drugs. The results of the antimicrobial activity of the ligand and its metal complexes against all tested bacterial and fungal strains are shown in Table 7 and Figure 11. All compounds inhibited the growth of bacteria (gram-negative and gram-positive), and exhibited antifungal activity. The complexes have an enhanced activity compared to the ligand due to the transition metal involved in coordination. In the case of ligand 
$\left(\mathbf{L}^{\mathbf{1}}\right)$, according to the results of the antibacterial activity screening, the Co(II) complexes possess effective and selective antibacterial activity against gram-positive bacterium (S. aureus), gram-negative bacterium (E. coli), and yeast (C. albicans). However, it was not effective against fingus A. flavus. On the other hand, in the case of ligand $\left(\mathrm{L}^{2}\right)$, the $\left[\left(\mathrm{L}^{2}\right)_{2} \mathrm{Pd}\right] \mathrm{Cl}_{2} \cdot 2 \mathrm{H}_{2} \mathrm{O}$ complexe was more toxic against $S$. aureus and $E$. coli compared with other complexes in $2 \mathrm{a}(\mathrm{L} 1)$ and $2 \mathrm{~b}(\mathrm{~L} 2)$. Thus, there was no toxic effect against $A$. flavus and $C$. albicans. The results of this investigation revealed that the $\mathrm{Co}$ (II) and Pd (II) complexes possess higher antimicrobial activity. Also, it is generally reported that free ligands show lower activity than complexes (Gulcan et al., 2012). Finally, it was suggested that the reason for this higher antimicrobial efficacy could be related to the inhibition of several structural enzymes that play a key role in vital metabolic pathways of the microorganisms.

Table 7. Biological activities of thiosemicarbazones ligands and their metal complexes against some microbial pathogens

\begin{tabular}{|c|c|c|c|c|c|}
\hline \multirow{2}{*}{\multicolumn{2}{|c|}{ Treatments }} & \multicolumn{4}{|c|}{ Inhibition Zone Diameter (mm / mg of complex) } \\
\hline & & $\begin{array}{c}\text { Esherishia } \\
\text { coli } \\
\left(\mathrm{G}^{-}\right)\end{array}$ & $\begin{array}{c}\text { Staphylococcus } \\
\text { aureus } \\
\left(\mathrm{G}^{+}\right)\end{array}$ & $\begin{array}{l}\text { Aspergillusflavus } \\
\text { (Fungus) }\end{array}$ & $\begin{array}{c}\text { Candida } \\
\text { albicans } \\
\text { (Yeast) }\end{array}$ \\
\hline \multicolumn{2}{|c|}{$\begin{array}{c}\text { Negative Control } \\
\text { DMSO }\end{array}$} & 0.0 & 0.0 & 0.0 & 0.0 \\
\hline \multicolumn{2}{|c|}{$\begin{array}{c}\text { Ampicillin } \\
\text { (Antibacterial agent) }\end{array}$} & 22 & 18 & 0.0 & 0.0 \\
\hline \multicolumn{2}{|c|}{$\begin{array}{l}\text { Amphotericin B } \\
\text { (Antifungal agent) }\end{array}$} & 0.0 & 0.0 & 17 & 19 \\
\hline 1 & $\mathrm{~L}^{1}$ ( Ligand 1) & 16 & 17 & 0.0 & 11 \\
\hline 2 & {$\left[\mathrm{~L}^{1} \mathrm{CuCl}_{2}\right] \mathrm{H}_{2} \mathrm{O}$} & 15 & 15 & 9 & 13 \\
\hline 3 & $\begin{array}{c}{\left[\left(\mathrm{L}^{1}\right)_{2} \mathrm{Co}\right] \mathrm{Cl}_{2^{-}}} \\
\mathrm{H}_{2} \mathrm{O} \\
\end{array}$ & 17 & 18 & 0.0 & 12 \\
\hline 4 & {$\left[\mathrm{~L}^{1} \mathrm{NiCl}_{2}\right] \mathrm{H}_{2} \mathrm{O}$} & 14 & 16 & 0.0 & 0.0 \\
\hline 5 & {$\left[\mathrm{~L}^{1} \mathrm{PdCl}_{2}\right] \mathrm{H}_{2} \mathrm{O}$} & 15 & 20 & 0.0 & 0.0 \\
\hline 6 & {$\left[\mathrm{~L}^{1} \mathrm{CuAC}_{2}\right] \mathrm{H}_{2} \mathrm{O}$} & 12 & 13 & 0.0 & 0.0 \\
\hline 7 & $\mathrm{~L}^{2}$ ( Ligand 2) & 15 & 15 & 0.0 & 0.0 \\
\hline 8 & {$\left[\mathrm{~L}^{2} \mathrm{CuCl}_{2}\right] \mathrm{H}_{2} \mathrm{O}$} & 12 & 12 & 0.0 & 9 \\
\hline 9 & {$\left[\mathrm{~L}^{2} \mathrm{CoCl}_{2}\right] 2 \mathrm{H}_{2} \mathrm{O}$} & 16 & 16 & 0.0 & 0.0 \\
\hline 10 & {$\left[\mathrm{~L}^{2} \mathrm{NiCl}_{2}\right] \mathrm{H}_{2} \mathrm{O}$} & 15 & 15 & 0.0 & 0.0 \\
\hline 11 & $\begin{array}{c}{\left[\left(\mathrm{L}^{2}\right)_{2} \mathrm{Pd}\right] \mathrm{Cl}_{2^{-}}} \\
2 \mathrm{H}_{2} \mathrm{O}\end{array}$ & 28 & 25 & 0.0 & 0.0 \\
\hline
\end{tabular}

DMSO: dimethylsulfoxide solvent; $\mathrm{G}^{-}$: Gram negative bacteria; $\mathrm{G}^{+}$: gram positive bacteria 


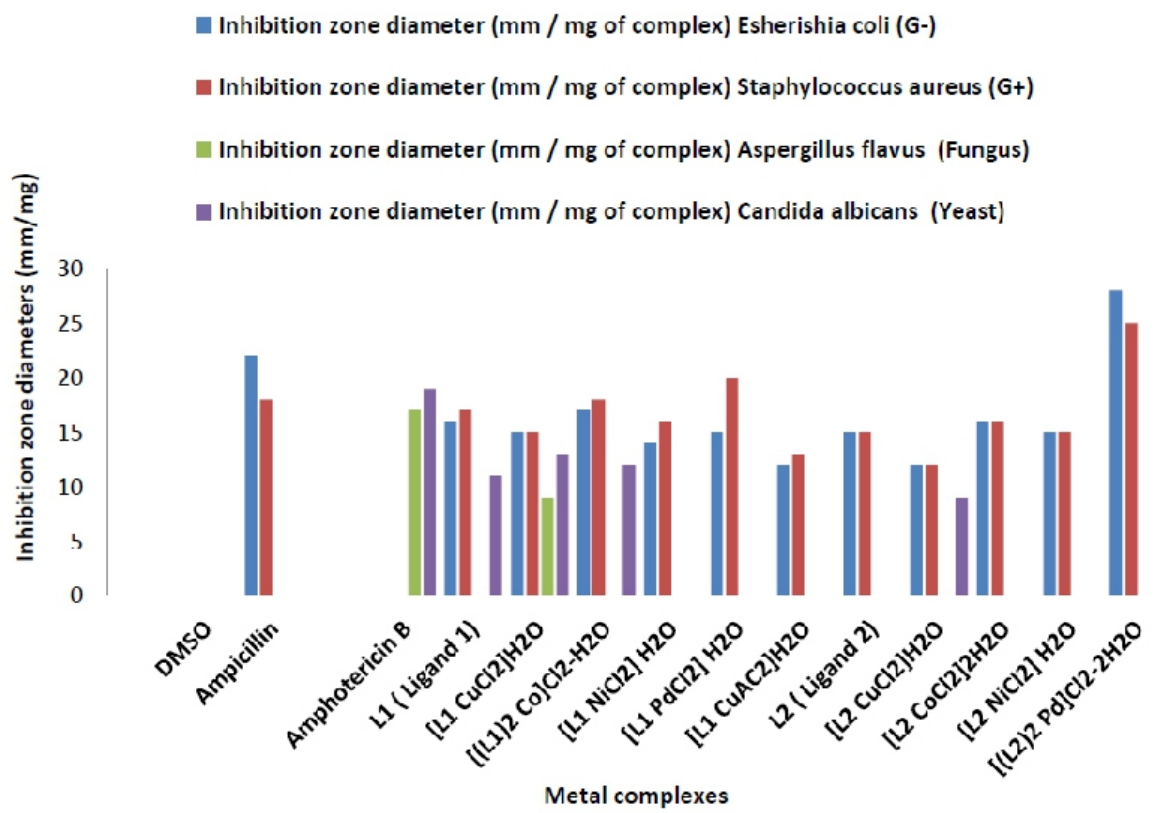

Figure11. Biological activities of thiosemicarbazones and their metal complexes

\section{Cytotoxic Activity}

The present study evaluated the antitumor activity of new synthesized derivatives of metal complexes $\mathrm{Cu}(\mathrm{II}), \mathrm{Ni}(\mathrm{II}), \mathrm{Co}(\mathrm{II})$, and Pd(II). Screening for antitumor activity included measurement of IC50 of MCF7 cell line in vitro by ELISA methods. Also, four serial concentrations (2.5, 5, 10 and 20 $\mu \mathrm{g} / \mathrm{ml}$ ) of metal complexes were tested in vitro cytotoxicity assay. The results of the cytotoxic activity in vitro were expressed as IC50 (the concentration of the compound in lgm $/ \mathrm{mL}$ that inhibits proliferation of the cells by $50 \%$ as compared to the untreated control cells) are given in Table 8 and Figure 12. The $\left[\mathrm{L}^{1} \mathrm{Pd} \mathrm{Cl}_{2}\right] \mathrm{H}_{2} \mathrm{O}$ complexes shows IC50 value of 4.6 $\mu \mathrm{g} / \mathrm{ml}$ toward human breast cancer cell lines (MCF-7) and that of other complexes were in the range of $2.7-4.3 \mu \mathrm{g} / \mathrm{ml}$ toward the former cells. Many studies indicated that thiosemicarbazides and their complexes are emerging as new class of experimental anticancer chemotherapeutic agents which show inhibitory activities against cancer. As thiosemicarbazones are nitrogen and sulfur atom donor ligands particularly for transition metal ions, remarkable biological activities are observed for these compounds which are related to their metal complexing ability in enzyme. 
Table 8. Cytotoxicity on MCF7 breast carcinoma cell line of thiosemicarbazones ligands and their metal complexes

\begin{tabular}{|c|c|c|c|c|c|c|c|c|c|c|c|}
\hline \multirow{2}{*}{$\begin{array}{c}\text { metal } \\
\text { complexes }\end{array}$} & 1 & 2 & 3 & 4 & 5 & 6 & 7 & 8 & 9 & 10 & 11 \\
\hline & 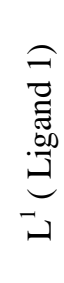 & 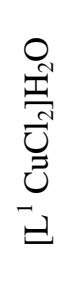 & 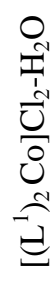 & 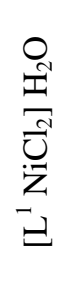 & 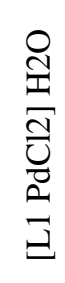 & 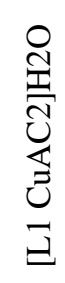 & 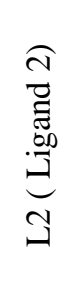 & 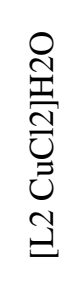 & 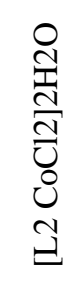 & 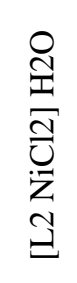 & 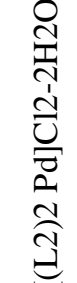 \\
\hline $\mathrm{IC} 50(\mu \mathrm{g} / \mathrm{mL}) *$ & 3.9 & 2.7 & 2.9 & 4.2 & 4.6 & 4.3 & 3.71 & 3.53 & 3.45 & 3.44 & 3.34 \\
\hline
\end{tabular}

* The IC50 values is the concentration of metal complexes $(\mu \mathrm{g} / \mathrm{ml})$ required to produce $50 \%$ inhibition of cell growth was calculated using sigmoidal dose response curve-fitting model.

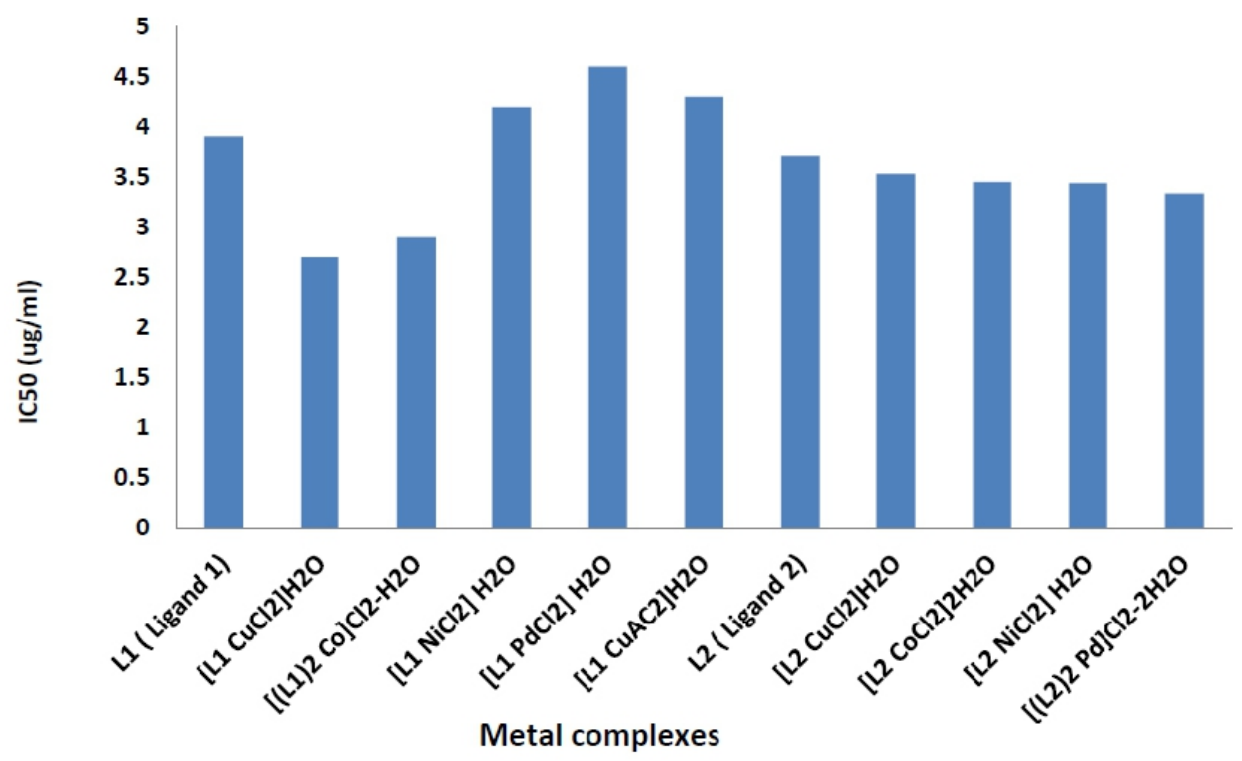

Figure 12. Cytotoxicity of metal complexes prepared chemically on MCF7 breast carcinoma cell line.

\section{Conclusion}

Benzofurane and naphthofuranethiosemicarbazones (ligands) and their $\mathrm{Cu}(\mathrm{II}), \mathrm{Co}(\mathrm{II}), \mathrm{Ni}(\mathrm{II})$, and $\mathrm{Pd}(\mathrm{II})$ complexes have been synthesized and characterized. 2a $\left(\mathrm{L}^{1}\right)$ and $2 \mathrm{~b}\left(\mathrm{~L}^{2}\right)$ thiosemicarbazones act as good corrosion inhibitor for cast iron in $1.0 \mathrm{M} \mathrm{H} \mathrm{H}_{2} \mathrm{SO}_{4}$. Therefore, the inhibition was attributed to the blockage of the active sites on cast iron by adsorption 
process. The obtained electrochemical data of deferent techniques were in good agreement. All data indicated that the \%IE increased along with the increase of the inhibitor concentration. The investigated compounds raise the polarization resistance and it acted as a mixed-type inhibitor in $1.0 \mathrm{M} \mathrm{H}_{2} \mathrm{SO}_{4}$ as indicated by LPR and the polarization data. EIS data indicated that when the inhibitors $2 \mathrm{a}\left(\mathrm{L}^{1}\right)$ and $2 \mathrm{~b}\left(\mathrm{~L}^{2}\right)$ were added, an increase in the charge transfer resistance and a decrease in double layer capacitances occur. This, hence, leads to an increase in \% IE. The free ligands show lower antibacterial activities than complexes. The Co(II) and Pd (II) complexes possess higher antimicrobial activity than free ligands and other complexes related to the inhibition of several structural enzymes that play a key role in vital metabolic pathways of the microorganisms. The $\left[\mathrm{L}^{1} \mathrm{Pd} \mathrm{Cl}_{2}\right] \mathrm{H}_{2} \mathrm{O}$ complexes shows IC50 value of $4.6 \mu \mathrm{g} / \mathrm{ml}$ toward human breast cancer cell lines (MCF-7) and that of other complexes were in the range of 2.7-4.3 $\mu \mathrm{g} / \mathrm{ml}$ toward the former cells related to their metal complexing ability in enzymes.

\section{Acknowledgment}

The authors wish to express their sincere gratitude to Qassim University, represented by the Deanship of Scientific Research, for the material support provided in the course of this research under the number 2823.

\section{References:}

1. Abd-El-Nabey B.A., Abdel-Gaber A.M., Elewady G.Y., El. Sadeek M.M., Abd-El-Rhman H. (2012). Int. J. Electrochem. Sci., 7, 11718 11733

2. Arab S.T and Emran K.M (2008). Materials Letters, 62, 1022 - 1032

3. Anirudhan T.S., Jalajamony S., and Sreekumari S.S (2013). J. Chem. Eng. Data, 58, 24-31.

4. Akyul Y.Y. and Anil H. (2004). Phytochemistry, 63, 939.

5. Badr G.E. (2009). CorrosSci; 51, 2529.

6. Badawy W. A., Nady H., Abd El Hafez G. M (2014). IJEIT, 4(3), 125

7. Bauer AW, Kirby WM, Sherris C, Turck .M (1966). Antibiotic susceptibility testing by a standardized single disk method, American Journal of Clinical Pathology, 45, 493-496.

8. Benedetti A.V., Sumodjo P.T.A., Nobe K., Cabot P.L., Proud W.G. (1995). Electrochim. Acta 40 (1995) 2657.

9. Bhat A.K., Bhamaria R.F., Patel M.R.Bellare R.A. and Deliwala C.V (1972). Indian J. chem.;10; 694. 
10. Carlsson B., Singh B. N., Temciuc M., Nilsson S., Mellin Y, Li. C., and Malm J. (2002). J. Med.Chem., 45, 623-630.

11. Chandra S. and Gupta L.K. (2005). SpectrochimicaActa Part A; $62 ; 1089$.

12. Cumhur Kirilmis (2009). Murat KOCA1, S“uleyman SERV`I2 and Seher G.'UR; Turk J Chem. 33, 375 - 384. ElDesoky A.M., Ahmed H.M., Ali E. (2015). Int. J. Electrochem. Sci.,10, 5112 -5129

13. Demertzi D.K., Miller J.R., Kourkoumelis N., Hadzikaaou S.K. and Demertzis M.A. (1999). Polyhedron1999; 18;1005.

14. Ferrari B.M., Fava G.G. Leporti E., Pelosi G., Rossi R., Tarasconi P., Albertini R.,Bonati A., Lunghi P. and Pinelli S. (1998). J.Inorganic Biochem; 70; 145.

15. Ferrari M.B., Capacchi S., Reffo G.,Aelosi G., Tarasconi P., Albertini R.,Pinellis S., Lunghi p. (2000). J. of Inorg. Biochem.; 81; 89.

16. Garg, B.S. and Jain, V.K (1988). Microchem. J., 38, 144-169.

17. Gulcan M., Sonmez M. and Berber I. (2012). Synthesis, characterization, and antimicrobial activity of a new pyrimidine Schiff base and its $\mathrm{Cu}(\mathrm{II}), \mathrm{Ni}(\mathrm{II}), \mathrm{Co}(\mathrm{II}), \mathrm{Pt}(\mathrm{II})$, and Pd(II) complexes. Turk J. Chem, 36, 189 - 200.

18. Guru S. Gadaginamath, Rajesh R. Kavali, \& Shashikanth R. Pujar (2003). SYNTHETIC COMMUNICATIONS; Vol. 33, No. 13, pp. 2285-2292.

19. Halli, M. B., Ravindra. S, Malipatil and Sumathi R. B. (2012). Int J Pharm Bio Sci; 3(4): (P) 547 - 557.

20. Hanumanagoud, H. and Basavaraja, K. M. (2013). Der PharmaChemica, 5(4):87-98.

21. Hammamm A.M., Ibrahim S.A., El-Gyar S.A., El-Gahami M.M (1988). Synth. React. Inorg. Met-Org. Chem. (18), 9.

22. Jiittner K, Lorenz W.J., Paatsch W., Kendig M., Mansfeld F., (1985)

23. Werkst. Korros. 36, 120.

24. Kashar T. I. (2010). Thermochimica Acta 507-508, 66-70

25. Kashar T.I. and Emran K.M. (2016). International Journal of Engineering Research and Management ,3(8).

26. Karakus N. and Sayin K. (2015). The investigation of corrosion inhibition efficiency on some benzaldehydethiosemicarbazones and their thioletautomers: Computational study, Journal of the Taiwan Institute of Chemical Engineers, 48,95-102.

27. Khanye S.D., Jiri G., Rosenthal P.J., Chibale K, Smith G.S (2011). J. Organomet. Chem., 696, 3296-3300.

28. Klayman D.L., Bartosevich J.F., Griffine T.S., Mason C.J. and Scovill J.P (1979). J. Med. Chem.; 22; 854. 
29. Klayman D.L., Scovill J.P., Bruce J. and Bartosevich J,J (1984). Med. Chem.;27; 84.

30. Lever A.B.P (1984). "Inorganic Electronic Spectroscopy" Elsevier Amest.2nd edit.

31. Liberta A. E. and West D.X. (1993). BioMetal 1992; 5; 121.

32. Lima R.L., Teixeira L.R., Carneiro T.M., and Beraldo H (1999). J. Braz; Chem. Soc., (10) 184.

33. Lobana T.S., Rekha, Butcher R.J., Castineiras A., Bermejo E. and Bharatam P.V (2006). Inorg.Chem. 45; 1535.

34. Lumb J. P. and Trauner D. J (2005). Am. Chem. Soc., 127, 2870.

35. Mansfeld F., Kendig M.W., Lorenz W.J. (1985). Electrochem. Soc. (132), 290.

36. Milan Sharda and Acharya, G. D. (2015). Der PharmaChemica, 7(8):25-29.

37. Musiol R., Jampilek J., Nycz J.E., Pesko M., Carroll J., Kralova K., Vejsova M., O’Mahony J., Coffey A., Mrozek A., Polanski J. (2010). Molecules, 15, 288-304.

38. Nishida Y. and Kida S. (1979). Coord. Chem. Rev. 27 (275).

39. Obot I.B., Obi-Egbedi N.O., Umoren S.A. (2009). Adsorption Characteristics and Corrosion Inhibitive Properties of Clotrimazole for Aluminium Corrosion in Hydrochloric Acid, Int. J. Electrochem. Sci., 4, 863 - 877

40. Parekh A.K. and Desai K.K (2006). Indian J. Chem. 45B; 1072.

41. Paul N. M., Taylor M., Kumar R., Deschamps J. R., Luedtke R. R., and Newman A (2008). H. J. Med. Chem., 51, 6095.

42. Pfaller, M. A., L. Burmeister, M. A. Bartlett, and M. G. Rinaldi (1988). Multicenter evaluation of four methods of yeast inoculum preparation. J. Clin. Microbiol. 26:1437-1441.

43. Serda M., Kalinowski D.S., Mrozek-Wilczkiewicz A., Musiol R., Szurko A., Ratuszna A., Pantarat N., Kovacevic Z., Merlot A.M., Richardson D.R., Polanski J (2012). Bioorg. Med. Chem. Lett. 2012, 22, 552

44. Singhal S., Arora S. and Agarwal S. (2014). Anticancer activities of thiosemicarbazides/thiosemicarbazones: a review. Int $J$ Pharm PharmSci, Vol 6, Issue 9, 34-41

45. Sharma S., Athar F., Maurya M.R., Azam A (2005). European J.Med.Chem.2005; 40;1414.

46. Sumathi .R. B and Halli M. B. (2014). Hindawi Publishing Corporation Bioinorganic Chemistry and Applications, Article ID 942162, 11 pages

47. Suresh P.K., Vijaybabu M.R., Arunkumar A., and Arunakaranl J. (2006). Journal of Ethnopharmacology, 105,246-250. 
48. Tahani I. Kashar (2013). European Scientific Journal, 9(33), 857 7881.

49. Tahani I. Kashar and Amal H. El-Sehli (2013). Journal of Chemical and Pharmaceutical Research, 2013, 5(11):474-483.

50. Xiang Zhou 1, Miao Li 2, Xiao-Bing Wang 1, Tao Wang 2 and LingYi Kong (2010). Molecules, 15, 8593-8601.

51. Yadav M., Behera D., Kumar S., and Sinha R.R (2013). Ind. Eng. Chem. Res., 52, 6318-6328. 